Portland State University

PDXScholar

Winter 3-19-2015

\title{
Genes Affecting the Repair and Survival of Escherichia coli Following Psoralen-Induced Damage: a DNA Interstrand Crosslinking Agent
}

Anthonige Vidya Perera

Portland State University

Follow this and additional works at: https://pdxscholar.library.pdx.edu/open_access_etds

Part of the Cell and Developmental Biology Commons

Let us know how access to this document benefits you.

\section{Recommended Citation}

Perera, Anthonige Vidya, "Genes Affecting the Repair and Survival of Escherichia coli Following PsoralenInduced Damage: a DNA Interstrand Crosslinking Agent" (2015). Dissertations and Theses. Paper 2195. https://doi.org/10.15760/etd.2192

This Thesis is brought to you for free and open access. It has been accepted for inclusion in Dissertations and Theses by an authorized administrator of PDXScholar. Please contact us if we can make this document more accessible: pdxscholar@pdx.edu. 
Genes Affecting the Repair and Survival of Escherichia coli Following Psoralen-Induced Damage: a DNA Interstrand Crosslinking Agent

by

Anthonige Vidya Perera

A thesis submitted in partial fulfillment of the requirements for the degree of

\author{
Master of Science \\ in \\ Biology
}

Thesis Committee:

Justin Courcelle, Chair

Michael Bartlett

Rahul Raghavan

Portland State University

2015 


\begin{abstract}
Photoactivated psoralens and other agents that form DNA interstrand crosslinks are highly cytotoxic and are useful in treating a range of diseases, including vitiligo, psoriasis, and some forms of cancer. Unlike many lesions that damage only one strand of the duplex DNA, DNA interstrand crosslinks form covalent bonds with both strands. Thus, repairing these lesions is complicated both by the lack of an undamaged strand to serve as a template for resynthesis following excision , as well as the potential to form double strand breaks if both strands are incised. A number of models have proposed that repair is likely to couple nucleotide excision repair with other repair pathways such as recombination, and/or translesion synthesis. However, several aspects of these models remain speculative, and how these medically relevant lesions are repaired by cells still remains elusive. In this study, I use Escherichia coli as a model organism to characterize which gene products contribute to survival in the presence of psoralen-induced DNA interstrand crosslinks.
\end{abstract}

In Chapter II, I demonstrate that although nucleotide excision repair initiates repair, not all subunits contribute equally to survival. Notably, $u v r C$ is less sensitive to psoralen-induced damage than either $u v r A$ or $u v r B$. I found that Cho, an alternative endonuclease, accounts for the increased resistance of $u v r C$ mutants and contributes to survival in the presence of UvrABC. Cho was not required following angelicin treatment, a psoralen derivative that only forms monoadducts, suggesting that Cho function is specific for interstrand crosslink repair. However, Cho, by itself, is not required for the initial incision and only modestly enhances the rate that psoralen crosslinks are incised 
in vivo.

Following incision, many of the intermediates in the repair process remain speculative. In Chapter III, I examine how recombination and translesion synthesis mutants contribute to survival of psoralen-induced damage. I show that both $\operatorname{rec} B C$ and recF contribute to survival, but that neither mutant is as hypersensitive as recA, potentially suggesting that pathways involving either single strand gaps or double strand break intermediates can occur during repair. Finally, I show that Polymerase V is responsible for the translesion synthesis that contributes to survival in the case of psoralen-induced damage in E.coli. 


\section{ACKNOWLEDGMENTS}

I would like to express my sincere gratitude to my adviser, Dr.Justin Courcelle for granting me the opportunity to work under him and providing me guidance throughout my graduate tenure. Secondly, I would like to thank my committee members Dr.Michael Bartlett and Dr.Rahul Raghavan for the excellent feedback and assistance with my written thesis. In addition, I would also like to thank Dr.Charmain Courcelle for her immense support and guidance. Lastly, I would like to extend my thanks to all my friends and family members for their support and encouragement. 
ABSTRACT

ACKNOWLEDGMENTS

LIST OF FIGURES

I INTRODUCTION

$\begin{array}{lll}\text { I INTRODUCTION } & 01\end{array}$

$\begin{array}{lll}\text { II REFERENCES } & 14\end{array}$

II Cho IS SPECIFICALLY REQUIRED FOR THE REPAIR OF DNA INTERSTRAND CROSSLINKS

$\begin{array}{lll}\text { I ABSTRACT } & 21\end{array}$

$\begin{array}{ll}\text { II INTRODUCTION } & 21\end{array}$

III MATERIALS AND METHODS 24

Bacterial Strains 24

Psoralen UV-A and Angelicin UV-A Survivals 26

UV-C Survival Assay 27

In vitro Plasmid Crosslinking Assay 27

In vivo Interstrand Crosslink Incision Assay 28

IV RESULTS 29

In contrast to UV-induced damage, $u v r C$ mutants are less sensitive to psoralen- induced adducts than either $u v r A$ or $u v r B$ mutants

Isogenic backgrounds are important when comparing sensitivities of the NER mutants to psoralen Cho accounts for the reduced sensitivity of $u v r C$ mutants and is required specifically in the presence of DNA interstand crosslinks, but not monoadducts

Purified plasmid treated with angelicin UV-A light forms minor product of DNA interstrand crosslinks

UvrC but not Cho is required for the initial incision of the crosslink in vivo 
V DISCUSSION

Model 1,Cho is required for repair of psoralen-induced lesions in a replication dependent manner

Model 2,Cho is required to increase the efficiency of psoralen-induced lesions in addition to UvrC

Model 3,Cho is responsible for the second incision step of the repair process at pyrone side of psoralen-induced lesions after recombination or translesion synthesis

VI REFERNCES

III ELEMENTS OF RECOMBINATION PATHWAY AND TRANSLESION POLYMERASES ARE REQUIRED FOR THE REPAIR OF DNA INTERSTRAND CROSSLINKS

I ABSTRACT 52

II INTRODUCTION 52

III MATERIALS AND METHODS 56

Bacterial Strains 56

Psoralen-UVA Survival Assay $\quad 56$

IV RESULTS $\quad 57$

Both RecFOR and RecBCD pathways contribute to the survival of psoralen-induced DNA damage $\quad 59$

Tranlesion Polymerase V, encoded by umuDC contributes to survival of psoralen-induced damage

UvrA coupled with translesion polymerases increases the sensitivity for the psoralen induced lesions

$\begin{array}{lll}\mathrm{V} & \text { DISCUSSION }\end{array}$

$\begin{array}{lll}\text { VI REFERENCES } & 65\end{array}$

$\begin{array}{ll}\text { TERMINAL REFERENCES } & 68\end{array}$

APPENDIX

ROLE OF BASE EXCISION REPAIR PATHWAY AND NER ACCESSORY PROTEINS IN SURVIVAL OF DNA INTERSTRAND CROSSLINKS 


\section{LIST OF FIGURES}

FIGURE $\quad$ PAGE

1-1: $\quad$ Structure of furocoumarins 04

1-2: Formation of DNA crosslinks in thymine (Asymmetrical lesion) 05

1-3: $\quad$ Models of Interstrand Crosslink Repair 13

2-1: $\quad$ In contrast to UV-induced damage, $u v r C$ mutants are less sensitive to psoralen-induced adducts than either $u v r A$ or $u v r B$ mutants

2-2: Isogenic backgrounds are important when comparing Sensitivities of the NER mutants to psoralen

2-3: $\quad$ Cho accounts for the reduced sensitivity of $u v r C$ mutants and is required specifically in the presence of both crosslink and monoadducts induced by both psoralen and angelicin

2-4: $\quad$ Purified plasmid treated with angelicin UV-A light forms minor product of DNA interstrand crosslinks

2-5: UvrC but not Cho is required for the initial incision of the crosslink in vivo

2-6: $\quad$ Model 1: Cho is required for repair of psoralen-induced lesions in a replication dependent manner

2-7: $\quad$ Model 2: Cho is required to increase the efficiency of psoralen-induced lesions in addition to UvrC

2-8: Model 3: Cho is responsible for the second incision step of the repair process at pyrone side of psoralen-induced lesions after recombination or translesion synthesis

3-1: Both RecFOR and RecBCD pathways contribute to the survival of psoraleninduced DNA damage

3-2: Tranlesion Polymerase V, encoded by $u m u D C$ contributes to survival of psoralen-induced damage

3-3: UvrA coupled with translesion polymerases increases the sensitivity for the psoralen induced lesions 


\section{CHAPTER I}

Psoralens are photoactive chemicals that belong to a family of plant chemicals called furocoumarins that naturally occur in the roots, leaves, and fruits of five plant families: Umbelliferae, Rutaceae, Moraceae, Leguminosae and Orchidaceous (1) These phototoxic chemicals have evolved in plants as a host defense mechanism against plant pathogens and herbivores (2). In plants, in addition to self-defense, these chemicals are also involved in stress response pathways and hormonal regulation (2). It has been found that these chemicals can act as alleochemical compounds, which inhibit seed germination and control growth under unfavorable environmental conditions (2). The phototoxicty of these compounds has not only been beneficial for plants, but has also been useful for humans since the ancient times. The therapeutic effects of these compounds combined with sunlight have been known for thousands of years treating various skin diseases. The most common furocoumarin, psoralen has been used in Egypt and India since 1200-2000 $\mathrm{BC}$ to treat skin disfiguring diseases such as vitiligo and leukoderma (1).

The modern medical applications of psoralen began with the isolation of the crystalline structure of 8-methoxypsoralen from the plant Ammi majaus in 1940s in Egypt (1). 8-methoxypsoralen combined with sunlight was first used in late 1940s to treat vitiligo $(1,3)$. Subsequently, it was found that artificial long wavelength ultraviolet light (UV-A, 320-400nm) activated 8-methoxypsoralen and inhibited epidermal DNA synthesis $(1,3,4)$. Although, the phototoxic effect of psoralen was known since early 1950s, the photochemotherapy or PUVA (psoralen+UVA), as it came to be known, was 
developed and extended to the treatment of psoriasis only in the early 1970s (1, 3-6). In recent years, PUVA therapy has been applied to the treatment of other medical conditions including cutaneous T cell lymphoma, prostate cancer, and stenosis (7-10).

\section{Psoralen and DNA Interstrand Crosslink Formation}

Psoralen, the most commonly found furocoumarin, is a tricyclic linear aromatic compound that contains a furan ring and a pyrone ring at each end of the molecule and (Figure 1-1) (11). Psoralen DNA interstrand crosslinks are asymmetrical and contain cycloaddition products of the pyrimidines on the furan and pyrone sides of the molecule. While psoralen does not exhibit sequence specificity for DNA binding, it preferentially forms covalent bonds with thymine. In the absence of ultraviolet light, psoralen intercalates between base pairs of the DNA helix and forms hydrogen bonds with pyrimidines. Upon exposure to the ultraviolet light $(>320 \mathrm{~nm})$, photoaddition occurs between the $\mathrm{C} 5=\mathrm{C} 6$ double bond of the pyrimidine and the $\mathrm{C} 4{ }^{\prime}=\mathrm{C} 5$ 'bond of the furan or $\mathrm{C}^{\prime}=\mathrm{C} 4$ ' of the pyrone (Figure 1-2) (11-13). After the first photoaddition, furan side monoadducts can absorb a second photon and become converted to a crosslink by cycloaddition between the pyrone double bond and a thymine on the opposite strand (Figure 1-2) (12-14). In contrast, nonlinear psoralen derivatives such as angelicin are only able to form monoadducts due to their angular structure (Figure 1-1) $(15,16)$. Thus, although angelicin is similar to psoralen in structure, it usually requires higher doses to have similar therapeutic effects $(15,16)$. 
Interstrand crosslinks covalently binds to two DNA strands preventing DNA strand separation, and represent an absolute block to processes such as DNA replication and transcription. The mutagenic and cytotoxic nature of photoadducted 8methoxypsoralen was demonstrated in the 1950s and these crosslinking agents remain among the most genotoxic compounds in use today $(1,6,8,9)$.

\section{Repair of the DNA interstrand crosslinks}

DNA interstrand crosslinks involve both strands of the duplex DNA and present a unique challenge for the cell to repair. Incisions on both strands of the DNA fragment to remove the crosslink would result in a loss of genetic information, but if the damage is unrepaired, would result lethality. Current models of the interstrand crosslink repair have proposed that multiple repair pathways are likely to be involved (17-21). However, whether and how these multiple repair pathways process these lesions is poorly understood and remains to be characterized. Therefore, in the next chapters I describe experiments designed to test aspects of two predominant models.

In both models, the first step of the interstrand crosslink repair involves nucleotide excision repair with subsequent steps performed either by recombination or translesion DNA synthesis pathways (17-22). The individual repair pathways and how they fit in the context of present models are described in the following sections. 


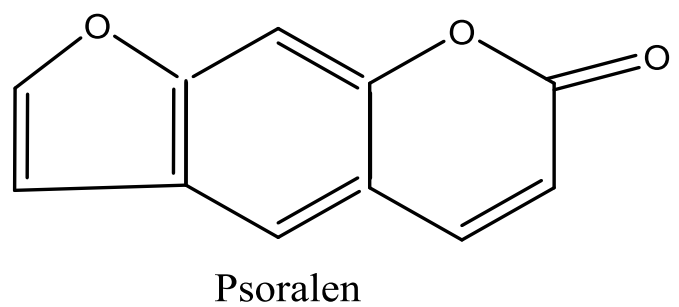

Psoralen

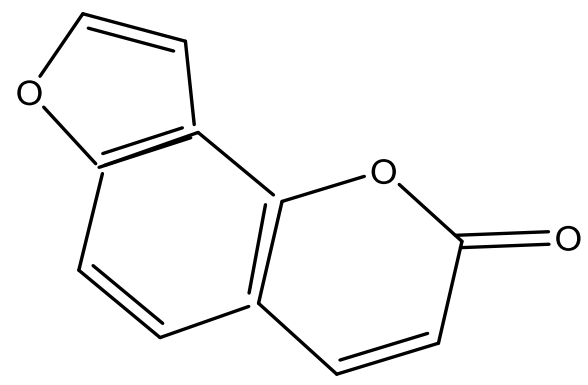

Angelicin

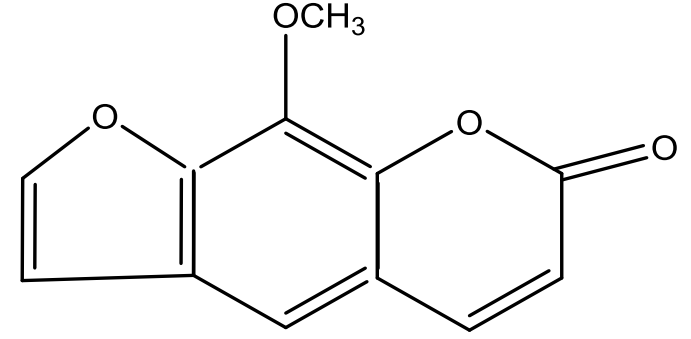

8-methoxypsoralen

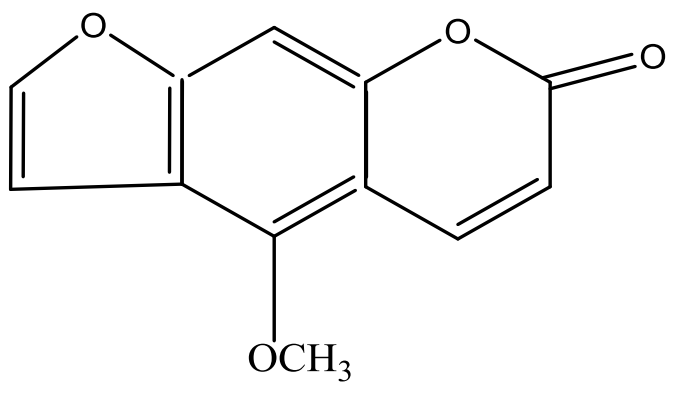

5-methoxypsoralen

\section{Figure 1-1: Structure of furocoumarins}

Furocoumains are tricyclic compounds containing furan and pyron rings. Linear forms of furocoumarins include psoralen and its derivatives. Angelicin is an example of an angular furocoumarins. 
<smiles>COc1c2ccoc2cc2ccc(=O)oc12</smiles>

8-methoxypsoralen<smiles>Cn1ccc(=O)[nH]c1=O</smiles>

Thymine

\section{UV-A (First Photon)}<smiles>COc1c2c(cc3ccoc13)C1C(C(=O)NC(=O)[C@H]1C)C1C(=O)NC(=O)C21</smiles>

monoadducts

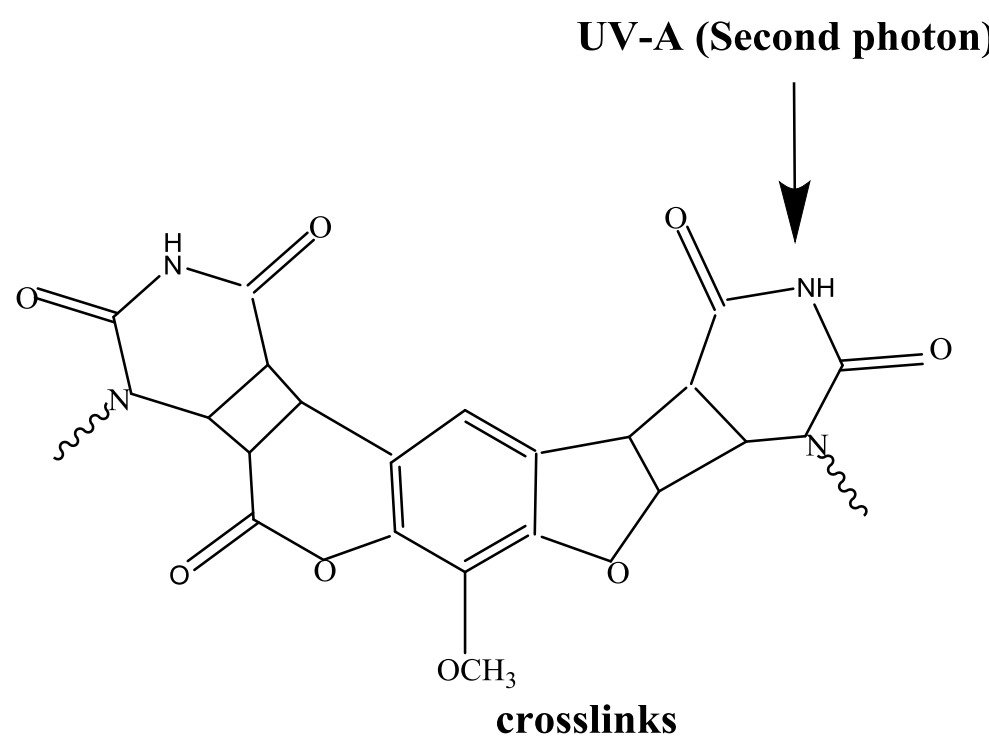

Figure1-2: Formation of DNA crosslinks in thymine (Asymmetrical lesion). Absorption of first photon covalently binds psoralen to the thymine in one strand and creates a monoadduct. Absorption of the second photon can convert monoadducts in to the crosslink by cycloaddition to the adjacent thymine. Adapted from (17) 


\section{Nucleotide Excision Repair}

Nucleotide excision repair (NER) is the primary repair pathways in Escherichia coli for repairing bulky DNA lesions (23-26). NER is highly conserved from bacteria to mammals and recognizes a wide range of chemically distinct lesions (Reviewed in (2729)). Removal occurs through a process of dual incisions in the lesion containing strand followed by a resynthesis step using the complementary strand as a template. UvrA is involved in the initial recognition of lesions in DNA(28). The protein is part of the ATP binding cassettes superfamily of ATPases that act as molecular matchmakers to affect several cellular processes, including DNA repair $(30,31)$. UvrA dimers form a groove that interacts with duplex DNA. Damage containing DNA distorts the helical backbone and causes a conformational change in the UvrA dimer, which in turn increases its DNA binding affinity $(30,32)$. $\mathrm{UvrA}_{2}$ binding to distorted DNA is transient and requires association with $\operatorname{UvrB}(31,33)$. The $(\mathrm{UvrA}){ }_{2} \mathrm{UvrB}$ complex associates stably with lesion containing DNA and recruits the third protein UvrC (31). UvrC possess two catalytic domains responsible for the 5'and 3' incisions of the damage containing DNA (34). The $\mathrm{N}$-terminus of UvrC contains the 3' endonuclease that makes its incision at the fourth or fifth phosphodiester bond 3' from the lesion (34-37). The 3' incision is thought to precede the 5 ' incision, which is catalyzed by the C-terminal domain and occurs at the eighth phosphodiester bond 5' from the lesion (34-37). The C-terminal domain also contains a helix hairpin helix motif that is essential for this reaction and shares $33 \%$ sequence homology with human ERCC1. ERCC1 together with XPF catalyze the 5' incision reaction during human nucleotide excision repair $(38,39)$. Following dual 
incisions of the lesion containing fragment, UvrD helicase unwinds the damaged DNA and displaces the (UvrA) ${ }_{2} \mathrm{UvrB}$ UvrC complex. The gap that is left is filled in by DNA polymerase I using the complementary strand as the template and is sealed by DNA ligase $(40,41)$.

In addition, $E$ coli also encodes a second endonuclease called Cho (Uvr $\underline{C}$ homolog) that is functions with the nucleotide excision repair pathway and is upregulated along with $u v r A$ and $u v r B$ in response to DNA damage as part of the SOS response (42, 43) . Notably $u v r C$ is not upregulated by the SOS response (43). Cho shows homology with the $\mathrm{N}$ - terminus of the $\mathrm{UvrC}$ and in vitro, catalyzes the 3' incision reaction at the eighth or ninth phosphodiester bond 3' to the lesion, four nucleotides downstream from where $\mathrm{UvrC}$ incises $\operatorname{DNA}(35,36,42)$. Similar to UvrC, Cho also requires UvrAB for its nuclease activity and is recruited to the DNA by UvrB; however, Cho binds to the UvrB at a different domain than UvrC (42). It is unclear why only a subset of bacteria encodes both UvrC and Cho or even what the function of Cho might be in these species and its role in vivo remains undefined (43). Several in vitro studies have suggested that Cho might make incisions at bulky lesions when UvrC is unable make the appropriate contacts with DNA (42). In support of this, bulky lesions such as cholesterol and menthol have been shown to be more efficiently incised by Cho than UvrC in vitro. However, whether Cho plays such a role in cells is unknown. In chapter II, I examine the contribution of Cho and the various nucleotide excision repair proteins to survival and repair of psoralen-induced lesions. 


\section{Recombinational Repair}

Homologous recombination is the main pathway by which cells repair doublestrand DNA breaks and daughter strand gaps in E coli (44-46). The primary protein of the homologous recombination is $\mathrm{Rec} \mathrm{A}$, which binds single stranded DNA and initiates strand exchange with homologous duplex DNA in vitro.(47-49) RecA loading onto single stranded DNA is facilitated by one of two pathways, $\operatorname{RecBCD}$ or $\operatorname{RecF}(44,50-52)$. RecBCD is a helicase/nuclease that unwinds and preferentially degrades the $5^{\prime}$ ends of DNA at double-strand DNA ends to generate 3 ' single strand overhanging DNA molecules which serve as substrates for $\operatorname{RecA} \operatorname{loading}(49,50,52-54)$. Alternatively, RecF, RecO, and RecR, are thought to act primarily at single strand gaps and single to double strand DNA junctions and operate to recruit RecA loading at these sites $(46,50$, $52,55-57)$.

\section{Translesion synthesis}

Translesion synthesis is an alternative to repair and allows replication to occur on templates containing lesions that have not been repaired $(18,58-60)$. In vitro, translesion DNA polymerases are able to incorporate nucleotides opposite to DNA lesions at higher efficiency than the replicative polymerase (DNA polymerase III) (61-66). While cell survival after DNA damage increases as a result of translesion synthesis, it is often associated with mutagenesis $(58,61,63,65,67,68)$.

E coli encode three translesion DNA polymerases, Pol II (polB), Pol IV (dinB) and Pol V (umиD and итиC) $(61,69)$. Pol IV and PolV are Y family polymerases, while 
Pol II polymerase is a B family polymerase $(61,69)$. These DNA polymerases are damage inducible and their expression is upregulated as a part of the SOS response (64, 68). In vitro, the $E$ coli translesion DNA polymerases show specificity for the type of DNA lesion they are able to bypass as well as sequence context variation in each activity $(58,61,62,70)$. For example, Pol V, but not Pol II or Pol IV increases cell survival following UV irradiation, while Pol IV contribute to viability after nitrofurazone treatment $(60,70)$.

\section{Fanconi anemia pathway and DNA interstrand crosslink repair in mammals}

In mammalian cells, Fanconi anemia pathway is the main DNA interstrand crosslink repair pathway during $\mathrm{S}$ phase (71-73). Fanconi anemia is a rare recessive disease that is characterized by hypersensitivity to interstrand crosslinks(71). Patients having mutations in Fanconi anemia genes are highly susceptible to cancer, present with bone marrow failure, growth retardation, hyperpigmentation, and kidney malfunction(71). Fanconi anemia includes more than 15 complementation groups and genes that can be divided into three main functional groups. Eight proteins FANCA, FANCB, FANCC, FANCE, FANCF, FANCG, FANCL, FANCM and two associated proteins , FAAP24 and FAAP100 form the core complex, which functions as a ubiquitin E3 ligase which mono-ubiquitinates the second functional complex, FANCD2/FANCI, known as ID complex $(71,74)$. Ubiquination of ID initiates the repair process following replication blockage by DNA interstrand crosslinks $(71,74)$. A third functional group consisting of FANCD1, FANCJ and FANCN(75). FANCM/FAAP24 within the core complex are thought to act as molecular sensors to detect replication fork blockage (76). 
Detection of replication fork arrest leads to FA core complex formation and ubiquitination of subsequent complexes, which is required to recruit downstream proteins for repair proteins $(71,73,74)$. The Fanconi anemia pathway is thought to recruit several endo- and exo-nucleases from other repair pathways to initiate the incision of crosslinks (72). However, it still remains unclear how these various proteins collaborate with each other to complete the repair process and their exact role in the FA pathway are not known. One of the main endonucleases recruited during replication fork blockage is XPF-ERCC1 endonuclease (77). This endonuclease is responsible for making the 5' within the NER pathway. However, XPG, the 3' endonuclease is not recruited by FA pathway (78-82). In addition, two other endonucleases are also thought to be involved in the later stages of the FA pathway, FAN1 - a structural dependent endonuclease having 5' endonuclease activity and weak 5' to 3' exonuclease activity (83-85), and Mus81-Eme1a structure-dependent 3' flap endonuclease associated with mismatch repair (86) .

The FA pathway is speculated to be specific for repairing lesions encountered during replication, and most models suggest that distinct mechanism may exist to repair crosslinks independent from replication (71-73). Similar to mammalian cells, prokaryotes may have a unique pathway designated to repair lesions that block DNA replication. I discuss this in relation to Cho function in in $E$ chapter II of my thesis.

\section{Models of DNA Interstrand Crosslinks}

Two models for prokaryotic interstrand crosslink repair involve nucleotide excision repair coupled with either recombinational (Figure 1-3A) or translesion 
synthesis (Figure 1-3B) (17).

Cole first proposed the nucleotide excision repair-homologous recombination model of interstrand crosslink repair (Figure 1.3A) based on survival assays of $u v r A$ and recA mutants in $E$ coli. Using psoralen interstrand crosslinks as his model lesion, Cole found that wild type cells were able to survive up to 65 lesions in their genomes $(20,21)$. In contrast, mutants in either $u v r A$ or $r e c A$ were able to survive 16 and 7 genomic lesions, respectively, while $u v r A$ recA mutant was able to tolerate less than one interstrand crosslink per genome. According to the model, UvrABC first makes dual incisions on the strand bearing the furan side adduct, leaving the oligonucleotide containing the crosslink covalently bound to its complementary strand. This intermediate is then proposed to serve as a substrate for RecA- mediated strand exchange. However, in vitro studies have demonstrated, that if true, it is likely to require significant exonucleolytic processing before RecA can recognize and initiate strand exchange $(22,87-89)$. The resulting three stranded structure is then proposed to a substrate for a second round of incisions by UvrABC to remove the remaining pyrone side adduct, leaving a single strand gapped molecule that is filled and sealed by DNA Pol I and DNA ligase activities $(22,87-90)$.

An alternative model was proposed to account for the possibility that no homologous DNA sequence is present, such as in cells that have just divided or are in stationary phase $(18,19,91)$. In this model, translesion synthesis substitutes for recombination to provide a template prior to the second round of incisions, however the remaining steps remain similar (Figure 1.3B) $(87,89)$. In vitro, DNA Pol II or Pol IV have been shown to be capable of bypassing different forms of DNA crosslinks $(18,19$, 
91).

It is important to note that the proteins proposed in these models are based primarily on the in vitro hypersensitive of mutants and the in vitro reconstitution of partial reaction steps. However, no intermediates have been observed in vivo to support these models Therefore, the overall goal of this thesis is to characterize the proteins and cellular pathways involved in the repair and survival of psoralen plus UVA-induced damage in $E$ coli. Chapter II describes experiments that determine which nucleotide excision repair proteins contribute to the removal of psoralen DNA interstrand crosslinks in vivo. In chapter III, I address the contribution of recombination proteins and translesion DNA polymerases to cellular survival following psoralen-UVA treatment. 


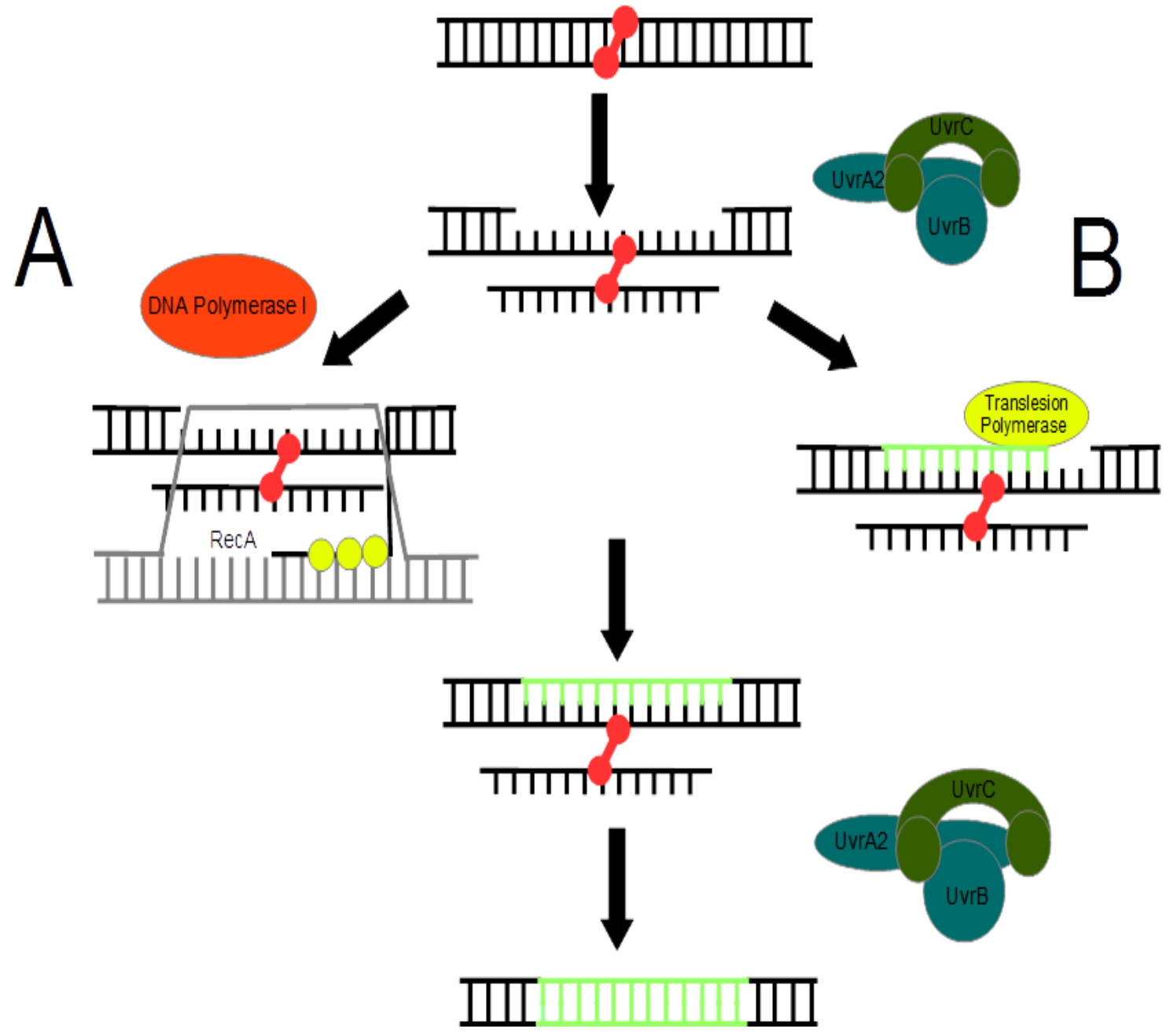

Figure 1-3: Models of Interstrand Crosslink Repair. A) Recombination dependent DNA interstrand crosslink repair. B) Translesion polymerases dependent interstrand crosslink repair. Adapted from. (17) 


\section{REFERENCES}

1. Pathak MA, Fitzpatrick TB. 1992. The evolution of photochemotherapy with psoralens and UVA (PUVA): 2000 BC to 1992 AD. Journal of Photochemistry and Photobiology B: Biology 14:3-22.

2. Bourgaud F, Hehn A, Larbat R, Doerper S, Gontier E, Kellner S, Matern U. 2006. Biosynthesis of coumarins in plants: a major pathway still to be unravelled for cytochrome P450 enzymes. Phytochem Rev 5:293-308.

3. Pathak MA, Fitzpatrick TB. 1959. Relationship of molecular configuration to the activity of furocoumarins which increase the cutaneous responses following long wave ultraviolet radiation. J Invest Dermatol 32:255-262.

4. Parrish JA, Stern RS, Pathak MA, Fitzpatrick TB. 1982. Photochemotherapy of Skin Diseases, p. 595-623. In Regan J, Parrish J (ed.), The Science of Photomedicine. Springer US.

5. Parrish JA, Fitzpatrick TB, Tanenbaum L, Pathak MA. 1974. Photochemotherapy of Psoriasis with Oral Methoxsalen and Longwave Ultraviolet Light. New England Journal of Medicine 291:1207-1211.

6. Gupta AK, Anderson TF. 1987. Psoralen photochemotherapy. Journal of the American Academy of Dermatology 17:703-734.

7. Querfeld C RSTKTM, et al. 2005. LOng-term follow-up of patients with earlystage cutaneous t-cell lymphoma who achieved complete remission with psoralen plus uv-a monotherapy. Archives of Dermatology 141:305-311.

8. Anderson TF, Voorhees JJ. 1980. Psoralen photochemotherapy of cutaneous disorders. Annual review of pharmacology and toxicology 20:235-257.

9. Baron ED, Stevens SR. 2003. Phototherapy for cutaneous T-cell lymphoma. Dermatologic Therapy 16:303-310.

10. March KL, Patton BL, Wilensky RL, Hathaway DR. 1993. 8Methoxypsoralen and longwave ultraviolet irradiation are a novel antiproliferative combination for vascular smooth muscle. Circulation 87:184-191.

11. Kitamura N, Kohtani S, Nakagaki R. 2005. Molecular aspects of furocoumarin reactions: Photophysics, photochemistry, photobiology, and structural analysis. Journal of Photochemistry and Photobiology C: Photochemistry Reviews 6:168185.

12. Hearst JE. 1989. Photochemistry of the psoralens. Chemical Research in Toxicology 2:69-75.

13. Hearst JE, Isaacs ST, Kanne D, Rapoport H, Straub K. 1984. The reaction of the psoralens with deoxyribonucleic acid. Quarterly Reviews of Biophysics 17:144.

14. Tessman JW, Isaacs ST, Hearst JE. 1985. Photochemistry of the furan-side 8methoxypsoralen-thymidine monoadduct inside the DNA helix. Conversion to diadduct and to pyrone-side monoadduct. Biochemistry 24:1669-1676.

15. Ashwood-Smith MJ, Grant E. 1977. Conversion of psoralen DNA monoadducts in E. coli to interstrand DNA cross links by near UV light (320-360 nm): Inability of angelicin to form cross links, in vivo. Experientia 33:384-386.

16. Bordin F, Carlassare F, Baccichetti F, Anselmo L. 1976. DNA repair and 
recovery in Escherichia coli after psoralen and angelicin photosensitization. Biochimica et Biophysica Acta (BBA) - Nucleic Acids and Protein Synthesis 447:249-259.

17. Dronkert MLG, Kanaar R. 2001. Repair of DNA interstrand cross-links. Mutation Research/DNA Repair 486:217-247.

18. Berardini M, Foster PL, Loechler EL. 1999. DNA Polymerase II (polB) Is Involved in a New DNA Repair Pathway for DNA Interstrand Cross-Links inEscherichia coli. Journal of Bacteriology 181:2878-2882.

19. Berardini M, Mackay W, Loechler EL. 1997. Evidence for a RecombinationIndependent Pathway for the Repair of DNA Interstrand Cross-Links Based on a Site-Specific Study with Nitrogen Mustard $\dagger$. Biochemistry 36:3506-3513.

20. Cole RS. 1973. Repair of DNA Containing Interstrand Crosslinks in Escherichia coli: Sequential Excision and Recombination. Proceedings of the National Academy of Sciences 70:1064-1068.

21. Cole RS, Levitan D, Sinden RR. 1976. Removal of psoralen interstrand crosslinks from DNA of Escherichia coli: Mechanism and genetic control. Journal of Molecular Biology 103:39-59.

22. Sladek FM, Munn MM, Rupp WD, Howard-Flanders P. 1989. In vitro repair of psoralen-DNA cross-links by RecA, UvrABC, and the 5'-exonuclease of DNA polymerase I. Journal of Biological Chemistry 264:6755-6765.

23. Setlow RB, Carrier WL. 1964. THE DISAPPEARANCE OF THYMINE DIMERS FROM DNA: AN ERROR-CORRECTING MECHANISM. Proceedings of the National Academy of Sciences of the United States of America 51:226-231.

24. Sancar A, Franklin KA, Sancar GB. 1984. Escherichia coli DNA photolyase stimulates uvrABC excision nuclease in vitro. Proceedings of the National Academy of Sciences 81:7397-7401.

25. Truglio JJ, Croteau DL, Van Houten B, Kisker C. 2006. Prokaryotic nucleotide excision repair: the UvrABC system. Chem Rev 106:233-252.

26. Pettijohn D, Hanawalt P. 1964. Evidence for repair-replication of ultraviolet damaged DNA in bacteria. Journal of Molecular Biology 9:395-410.

27. Sancar A. 1996. DNA excision repair. Annu Rev Biochem 65:43-81.

28. Van Houten B. 1990. Nucleotide excision repair in Escherichia coli. Microbiol Rev 54:18-51.

29. Snowden A, Kow YW, Van Houten B. 1990. Damage repertoire of the Escherichia coli UvrABC nuclease complex includes abasic sites, base-, damage analogues, and lesions containing adjacent 5' or 3' nicks. Biochemistry 29:72517259 .

30. Seeberg E, Steinum AL. 1982. Purification and properties of the uvrA protein from Escherichia coli. Proc Natl Acad Sci U S A 79:988-992.

31. Verhoeven EEA, Wyman C, Moolenaar GF, Goosen N. 2002. The presence of two UvrB subunits in the UvrAB complex ensures damage detection in both DNA strands. The EMBO Journal 21:4196-4205.

32. Sancar A, Reardon JT. 2004. Nucleotide Excision Repair in E. Coli and Man, p. 43-71. In Wei Y (ed.), Advances in Protein Chemistry, vol. Volume 69. Academic 
Press.

33. Verhoeven EEA, Wyman C, Moolenaar GF, Hoeijmakers JHJ, Goosen N. 2001. Architecture of nucleotide excision repair complexes: DNA is wrapped by UvrB before and after damage recognition. The EMBO Journal 20:601-611.

34. Verhoeven EEA, van Kesteren M, Moolenaar GF, Visse R, Goosen N. 2000. Catalytic Sites for 3' and 5' Incision of Escherichia coli Nucleotide Excision Repair Are Both Located in UvrC. Journal of Biological Chemistry 275:51205123.

35. Sancar A, Rupp WD. 1983. A novel repair enzyme: UVRABC excision nuclease of Escherichia coli cuts a DNA strand on both sides of the damaged region. Cell 33:249-260.

36. Yeung AT, Mattes WB, Oh EY, Grossman L. 1983. Enzymatic properties of purified Escherichia coli uvrABC proteins. Proceedings of the National Academy of Sciences 80:6157-6161.

37. Moolenaar GF, Franken KLMC, Dijkstra DM, Thomas-Oates JE, Visse R, van de Putte P, Goosen N. 1995. The C-terminal Region of the UvrB Protein of Escherichia coli Contains an Important Determinant for UvrC Binding to the Preincision Complex but Not the Catalytic Site for 3'-Incision. Journal of Biological Chemistry 270:30508-30515.

38. Moolenaar GF, Uiterkamp RS, Zwijnenburg DA, Goosen N. 1998. The Cterminal region of the Escherichia coli UvrC protein, which is homologous to the C-terminal region of the human ERCC1 protein, is involved in DNA binding and 5'-incision. Nucleic Acids Res 26:462-468.

39. Singh S, Folkers GE, Bonvin AMJJ, Boelens R, Wechselberger R, Niztayev A, Kaptein R. 2002. Solution structure and DNA-binding properties of the Cterminal domain of UvrC from E.coli. The EMBO Journal 21:6257-6266.

40. Sibghat U, Sancar A, Hearst JE. 1990. The repair patch of E. coli (A)BC excinuclease. Nucleic Acids Res 18:5051-5053.

41. Husain I, Van Houten B, Thomas DC, Abdel-Monem M, Sancar A. 1985. Effect of DNA polymerase I and DNA helicase II on the turnover rate of UvrABC excision nuclease. Proc Natl Acad Sci U S A 82:6774-6778.

42. Moolenaar GF, van Rossum-Fikkert S, van Kesteren M, Goosen N. 2002. Cho, a second endonuclease involved in Escherichia coli nucleotide excision repair. Proceedings of the National Academy of Sciences 99:1467-1472.

43. Van Houten B, Eisen JA, Hanawalt PC. 2002. A cut above: Discovery of an alternative excision repair pathway in bacteria. Proceedings of the National Academy of Sciences 99:2581-2583.

44. Kuzminov A. 1999. Recombinational Repair of DNA Damage inEscherichia coli and Bacteriophage $\lambda$. Microbiology and Molecular Biology Reviews 63:751-813.

45. Michel B, Ehrlich SD, Uzest M. 1997. DNA double-strand breaks caused by replication arrest. The EMBO Journal 16:430-438.

46. Yu-Chin T, Jai-Li H, Wang T-CV. 1994. Involvement of RecF pathway recombination genes in postreplication repair in UV-irradiated Escherichia coli cells. Mutation Research/DNA Repair 315:1-9.

47. Kahn R, Cunningham RP, DasGupta C, Radding CM. 1981. Polarity of 
heteroduplex formation promoted by Escherichia coli recA protein. Proceedings of the National Academy of Sciences 78:4786-4790.

48. Konforti BB, Davis RW. 1987. 3' homologous free ends are required for stable joint molecule formation by the RecA and single-stranded binding proteins of Escherichia coli. Proceedings of the National Academy of Sciences 84:690-694.

49. Cassuto E, West SC, Howard-Flanders P. 1982. Can recA protein promote homologous pairing between duplex regions of DNA? The EMBO Journal 1:821825.

50. Courcelle J, Carswell-Crumpton C, Hanawalt PC. 1997. recF and recR are required for the resumption of replication at DNA replication forks in Escherichia coli. Proceedings of the National Academy of Sciences 94:37143719.

51. Anderson DG, Kowalczykowski SC. 1997. The Translocating RecBCD Enzyme Stimulates Recombination by Directing RecA Protein onto ssDNA in a $\chi$ Regulated Manner. Cell 90:77-86.

52. Churchill JJ, Anderson DG, Kowalczykowski SC. 1999. The RecBC enzyme loads RecA protein onto ssDNA asymmetrically and independently of $\chi$, resulting in constitutive recombination activation. Genes \& Development 13:901-911.

53. Taylor AF, Smith GR. 2003. RecBCD enzyme is a DNA helicase with fast and slow motors of opposite polarity. Nature 423:889-893.

54. Dillingham MS, Spies M, Kowalczykowski SC. 2003. RecBCD enzyme is a bipolar DNA helicase. Nature 423:893-897.

55. Chow K-H, Courcelle J. 2004. RecO Acts with RecF and RecR to Protect and Maintain Replication Forks Blocked by UV-induced DNA Damage in Escherichia coli. Journal of Biological Chemistry 279:3492-3496.

56. Chen Z, Ricigliano JW, Klessig DF. 1993. Purification and characterization of a soluble salicylic acid-binding protein from tobacco. Proceedings of the National Academy of Sciences 90:9533-9537.

57. Courcelle J, Crowley DJ, Hanawalt PC. 1999. Recovery of DNA replication in UV-irradiated Escherichia coli requires both excision repair and recF protein function. J Bacteriol 181:916-922.

58. Ho TV, Schärer OD. 2010. Translesion DNA synthesis polymerases in DNA interstrand crosslink repair. Environmental and Molecular Mutagenesis 51:552566.

59. Kumari A, Minko IG, Harbut MB, Finkel SE, Goodman MF, Lloyd RS. 2008. Replication Bypass of Interstrand Cross-link Intermediates by Escherichia coli DNA Polymerase IV. Journal of Biological Chemistry 283:27433-27437.

60. Courcelle CT, Belle JJ, Courcelle J. 2005. Nucleotide Excision Repair or Polymerase V-Mediated Lesion Bypass Can Act To Restore UV-Arrested Replication Forks in Escherichia coli. Journal of Bacteriology 187:6953-6961.

61. Fijalkowska IJ, Schaaper RM, Jonczyk P. 2012. DNA replication fidelity in Escherichia coli: a multi-DNA polymerase affair, vol. 36.

62. Ho TV, Guainazzi A, Derkunt SB, Enoiu M, Schärer OD. 2011. Structuredependent bypass of DNA interstrand crosslinks by translesion synthesis polymerases. Nucleic Acids Research 39:7455-7464. 
63. Bagg A, Kenyon CJ, Walker GC. 1981. Inducibility of a gene product required for UV and chemical mutagenesis in Escherichia coli. Proceedings of the National Academy of Sciences 78:5749-5753.

64. Iwasaki H, Nakata A, Walker GC, Shinagawa H. 1990. The Escherichia coli polB gene, which encodes DNA polymerase II, is regulated by the SOS system. Journal of Bacteriology 172:6268-6273.

65. Reuven NB, Arad G, Maor-Shoshani A, Livneh Z. 1999. The Mutagenesis Protein UmuC Is a DNA Polymerase Activated by UmuD', RecA, and SSB and Is Specialized for Translesion Replication. Journal of Biological Chemistry 274:31763-31766.

66. Bonner CA, Hays S, McEntee K, Goodman MF. 1990. DNA polymerase II is encoded by the DNA damage-inducible dinA gene of Escherichia coli. Proceedings of the National Academy of Sciences 87:7663-7667.

67. Wagner J, Gruz P, Kim S-R, Yamada M, Matsui K, Fuchs RPP, Nohmi T. 1999. The dinB Gene Encodes a Novel E. coli DNA Polymerase, DNA Pol IV, Involved in Mutagenesis. Molecular Cell 4:281-286.

68. Napolitano R, Janel-Bintz R, Wagner J, Fuchs RPP. 2000. All three SOSinducible DNA polymerases (Pol II, Pol IV and Pol V) are involved in induced mutagenesis. The EMBO Journal 19:6259-6265.

69. Lehmann AR, Niimi A, Ogi T, Brown S, Sabbioneda S, Wing JF, Kannouche PL, Green CM. 2007. Translesion synthesis: Y-family polymerases and the polymerase switch. DNA Repair 6:891-899.

70. Sanders LH, Rockel A, Lu H, Wozniak DJ, Sutton MD. 2006. Role of Pseudomonas aeruginosa dinB-Encoded DNA Polymerase IV in Mutagenesis. Journal of Bacteriology 188:8573-8585.

71. Knipscheer P, Raschle M, Smogorzewska A, Enoiu M, Ho TV, Scharer OD, Elledge SJ, Walter JC. 2009. The Fanconi anemia pathway promotes replication-dependent DNA interstrand cross-link repair. Science 326:1698-1701.

72. Williams HL, Gottesman ME, Gautier J. 2012. Replication-independent repair of DNA interstrand crosslinks. Mol Cell 47:140-147.

73. Williams HL, Gottesman ME, Gautier J. 2013. The differences between ICL repair during and outside of S phase. Trends Biochem Sci 38:386-393.

74. Patel KJ, Joenje H. 2007. Fanconi anemia and DNA replication repair. DNA Repair 6:885-890.

75. Castillo Bosch P, Segura-Bayona S, Koole W, van Heteren JT, Dewar JM, Tijsterman M, Knipscheer P. 2014. FANCJ promotes DNA synthesis through G-quadruplex structures. Embo J 5.

76. Huang M, Kim JM, Shiotani B, Yang K, Zou L, D'Andrea AD. 2010. The FANCM/FAAP24 Complex Is Required for the DNA Interstrand CrosslinkInduced Checkpoint Response. Molecular Cell 39:259-268.

77. Klein Douwel D, Boonen Rick ACM, Long David T, Szypowska Anna A, Räschle M, Walter Johannes C, Knipscheer P. 2014. XPF-ERCC1 Acts in Unhooking DNA Interstrand Crosslinks in Cooperation with FANCD2 and FANCP/SLX4. Molecular Cell 54:460-471.

78. Clingen PH, De Silva IU, McHugh PJ, Ghadessy FJ, Tilby MJ, Thurston DE, 
Hartley JA. 2005. The XPF-ERCC1 endonuclease and homologous recombination contribute to the repair of minor groove DNA interstrand crosslinks in mammalian cells produced by the pyrrolo[2,1-c][1,4]benzodiazepine dimer SJG-136. Nucleic Acids Research 33:3283-3291.

79. Park C-H, Bessho T, Matsunaga T, Sancar A. 1995. Purification and Characterization of the XPF-ERCC1 Complex of Human DNA Repair Excision Nuclease. Journal of Biological Chemistry 270:22657-22660.

80. Bhagwat N, Olsen AL, Wang AT, Hanada K, Stuckert P, Kanaar R, D'Andrea A, Niedernhofer LJ, McHugh PJ. 2009. XPF-ERCC1 Participates in the Fanconi Anemia Pathway of Cross-Link Repair. Molecular and Cellular Biology 29:6427-6437.

81. Matsunaga T, Park C-H, Bessho T, Mu D, Sancar A. 1996. Replication Protein A Confers Structure-specific Endonuclease Activities to the XPF-ERCC1 and XPG Subunits of Human DNA Repair Excision Nuclease. Journal of Biological Chemistry 271:11047-11050.

82. Matsunaga T, Mu D, Park C-H, Reardon JT, Sancar A. 1995. Human DNA Repair Excision Nuclease: ANALYSIS OF THE ROLES OF THE SUBUNITS INVOLVED IN DUAL INCISIONS BY USING ANTI-XPG AND ANTIERCC1 ANTIBODIES. Journal of Biological Chemistry 270:20862-20869.

83. Smogorzewska A, Desetty R, Saito TT, Schlabach M, Lach FP, Sowa ME, Clark AB, Kunkel TA, Harper JW, Colaiácovo MP, Elledge SJ. 2010. A Genetic Screen Identifies FAN1, a Fanconi Anemia-Associated Nuclease Necessary for DNA Interstrand Crosslink Repair. Molecular Cell 39:36-47.

84. Kottemann MC, Smogorzewska A. 2013. Fanconi anaemia and the repair of Watson and Crick DNA crosslinks. Nature 493:356-363.

85. Liu T, Ghosal G, Yuan J, Chen J, Huang J. 2010. FAN1 Acts with FANCIFANCD2 to Promote DNA Interstrand Cross-Link Repair. Science 329:693-696.

86. Hanada K, Budzowska M, Modesti M, Maas A, Wyman C, Essers J, Kanaar R. 2006. The structure-specific endonuclease Mus81-Eme1 promotes conversion of interstrand DNA crosslinks into double-strands breaks. The EMBO Journal 25:4921-4932.

87. Van Houten B, Gamper H, Hearst JE, Sancar A. 1986. Construction of DNA substrates modified with psoralen at a unique site and study of the action mechanism of $A B C$ excinuclease on these uniformly modified substrates. Journal of Biological Chemistry 261:14135-14141.

88. Van Houten B, Gamper H, Hearst JE, Sancar A. 1988. Analysis of sequential steps of nucleotide excision repair in Escherichia coli using synthetic substrates containing single psoralen adducts. Journal of Biological Chemistry 263:1655316560.

89. Van Houten B, Gamper H, Holbrook SR, Hearst JE, Sancar A. 1986. Action mechanism of $\mathrm{ABC}$ excision nuclease on a DNA substrate containing a psoralen crosslink at a defined position. Proceedings of the National Academy of Sciences 83:8077-8081.

90. Sladek FM, Melian A, Howard-Flanders P. 1989. Incision by UvrABC excinuclease is a step in the path to mutagenesis by psoralen crosslinks in 
Escherichia coli. Proc Natl Acad Sci U S A 86:3982-3986.

91. Wang X, Peterson CA, Zheng H, Nairn RS, Legerski RJ, Li L. 2001. Involvement of Nucleotide Excision Repair in a Recombination-Independent and Error-Prone Pathway of DNA Interstrand Cross-Link Repair. Molecular and Cellular Biology 21:713-720. 


\section{CHAPTER II}

\section{Cho IS SPECIFICALLY REQUIRED FOR THE REPAIR OF DNA INTERSTRAND CROSSLINKS}

\section{ABSTRACT}

DNA interstrand crosslinks are complex lesions that covalently bind to both strands of the duplex DNA. The repair of interstrand crosslinks is proposed to be initiated by the NER repair pathway. In this study, we characterized the role of NER pathway in the presence of psoralen-induced lesions, which forms both interstrand crosslinks and monoadducts. Unexpectedly, we observed that the nucleotide excision repair mutants exhibit differential sensitivity to psoralen-induced damage, with $u v r C$ mutants being less sensitive than either $u v r A$ or $u v r B$. Furthermore, we found that Cho, an alternative endonuclease, is responsible for the reduced hypsersensitivity of $u v r C$ mutants, and is required specifically in the presence of DNA interstrand crosslinks. Three models are discussed for the mechanism by which Cho may be acting in this pathway.

\section{INTRODUCTION}

Psoralens are tricyclic asymmetrical compounds containing furan and pyron rings, and bind DNA nonspecifically with a preference for pyrimidines forming noncovalent bonds(17, 18). Upon absorption of UV-A light, a covalent bond forms through photoaddition between the $\mathrm{C} 5=\mathrm{C} 6$ double bond of the pyrimidine and the psoralen's $\mathrm{C}^{\prime}=\mathrm{C} 5^{\prime}$ bond of the furan or $\mathrm{C}^{\prime}=\mathrm{C} 4^{\prime}$ of the pyrone moiety $(17,18,44)$. Absorption of a second photon results in photo addition on the remaining furan or pyrone with a second pyrimidine, creating a DNA interstrand crosslink $(17,18,23)$. Thus, psoralen-induced 
damage consists of both monoadducts and DNA interstrand crosslinks. Interstrand crosslinks covalently bind both strands of the duplex DNA, thereby inhibiting any cellular process that requires strand denaturation, such as transcription and replication. This inhibition is generally considered to be the reason for the potency of their toxicity, and use in treating different skin diseases such as vitiligo, psoriasis, and as a chemotherapeutic for some forms of cancer $(16,22,32,36,37)$.

Several models have been proposed as to how DNA interstrand crosslinks are repaired, although many aspects of these models still remain unknown. A feature common to all these models is that the repair process is initiated by nucleotide excision repair, followed by the sequential action of other DNA repair processes, such as recombination or translesion synthesis $(2,7,15)$.

Nucleotide excision repair pathway is the primary pathway for repairing bulky DNA lesions in cells $(39,45,46)$. In Escherichia coli the incision complex for this pathway is made up of UvrA, UvrB and $\mathrm{UvrC}(45)$. UvrA forms a homodimer that has a high affinity for damaged DNA relative to non-damaged DNA $(34,39,45)$. In a presence of a distorting lesion, a complex consisting of $\mathrm{UvrA}_{2} \mathrm{~B}$ specifically binds to the strand containing the lesion $(34,35)$. Binding of the $\mathrm{UvrA}_{2} \mathrm{~B}$ complex recruits the $\mathrm{UvrC}$ endonuclease, which makes an initial incision located on the fourth or fifth phosphodiester bond 3' to the lesion, immediately followed by a second incision at eighth phosphodiester bond on 5 ' side $(29,40,50)$. After the incision step, the UvrD helicase displaces the UvrA2BC complex and along with the 12-13 bp segment containing the lesion before DNA polymerase I and ligase re-synthesize and seal this segment using the 
undamaged strand as a template (47).

Several studies support the idea that NER is involved in the repair of interstrand crosslinks (4-7). In vivo, mutants defective in any one of the nucleotide excision repair genes are hypersensitive to crosslinking agents $(6,7)$. Furthermore, all three NER mutants are defective in their ability to incise DNA containing interstrand crosslinks in vivo, as measured in alkaline $\mathrm{CsCl}$ gradients $(6,7)$. In vitro, $\mathrm{UvrA} \mathrm{UvrB}$ and $\mathrm{UvrC}$ are capable of incising oligonucleotides or plasmids containing a psoralen-induced interstrand crosslink, with dual incisions occurring predominantly on the strand containing the furan moiety $(40,42,43,49)$.

Based on these observations, and other lesions known to be repaired by nucleotide excision repair, it was inferred that all three subunits of the repair complex were required and contributed equally to the crosslink repair. However, a recent study reported that $u v r B$ mutants were more sensitive to psoralen-induced damage than either $u v r A$ or $u v r C$, suggesting a potentially unique mechanism of repair for these lesions (26). While this represents a potentially important observation, they also appeared to contradict a number of earlier studies that suggested $u v r A$ and $u v r B$ mutants are equally sensitive to psoralen treatment $(3,13)$.

Thus to characterize the comparative roles of the NER proteins in the processing and repairing of DNA interstrand crosslinks, we constructed isogenic mutant strains lacking each of the nucleotide excision genes and characterized their ability to survive and incise psoralen-induced DNA damage. In do so, we observed that a mutant of the 
nuclease subunit, UvrC, was less sensitive to psoralen-induced damage. We found that an alternative nuclease, Cho, could account for the reduced hypersensitivity, and that Cho function appears to be specific for the repair of interstrand crosslinks.

\section{MATERIALS AND METHODS}

\section{$\underline{\text { Bacterial Strains }}$}

The parental strain used in this study was SR108, a thyA36 deoC2 derivative of W3110. Isogenic strains lacking $u v r A$ (HL952), $u v r C$ (HL925), and $u v r D$ (CL1302), were constructed by standard P1 transduction and have been reported previously $(19,20,33)$. The cho gene was replaced from codons 4 to 280 with cat, conferring chloramphenicol resistance, using PCR replacement with the primers,

5'-ggatagataaccagcattcggagtcaacagtggtacggcgatgagacgttgatcggcac-3'

and

5'-ctcgctggtcattcgccggatcaagttcagtaatttcatactttcgaatttctgccattc -3',

followed by recombineering into DY329 to generate CL904(19) .The uvrB gene was replaced from codons 1 to 672 with cat using PCR replacement with the primers, 5'-attacatacctgcccgcccaactccttcaggtagcgactcatgagacgttgatcggcac-3'

and

5'-ggctgttttccgtttgtcatcagtcttcttcgctatcctgctttcgaatttctgccattc-3',

followed by recombineering into DY329 to generate CL1673(53). CL908 (SR108 cho::cat) and CL1735 (SR108 uvrB::cat) were constructed by P1 transduction of cho::cat 
and uvrB::cat from CL904 and CL1673, respectively, into SR108. CL2155 (SR108 cho::cat uvrC297::Tn10) was generated by P1 transduction of the uvrC297::Tn10 allele from HL925 into CL908.

The parental strain, AB1157 (thr-1 leuB6 proA2 his-4 argE3 thi-1 lacY1 ara-14 xyl-5 mtl-1 tsx-33 rpsL31 supE44 galK2) has been reported previously(14).AB1886 (uvrA6), AB1885 (uvrB5), and $\mathrm{AB} 2498$ (uvrC34) are nitrous acid-mutagenized derivatives of AB1157 and have been previously reported HL759 (uvrA6 zjd::Tn5) has been reported previously (14) .The $u v r B 5$ allele from AB1885 was linked to kanamycin resistance in two steps. First, the kanR gene was inserted $23 \mathrm{bp}$ downstream from $m n g B$ using PCR insertion with the primers,

5'-gttaccggcttgcctgaatagcaatcaaaccgaagccacatgtgacggaagatcacttcg-3'

and

5'-atgaacaaagcgccctttgtcaacaatctggccgcgcataaccagcaatagacataagcg-3',

followed by recombineering into DY329 to generate CL2301. mngB::kan, from CL2301, was then transduced into AB1885 using standard P1 transduction to generate CL2337. The $u v r B 5$ allele is $~ 50 \%$ cotransducible with mngB::kan. The uvrC34 allele from AB2498 was linked to kanamycin resistance in two steps. First, the kanR gene was inserted 106 bp upstream from tor $Y$ using PCR insertion with the primers,

5'-ggatagataaccagcattcggagtcaacagtggtacggcgatgagacgttgatcggcac-3' 
and

5'ctcgctggtcattcgccggatcaagttcagtaatttcatactttcgaatttctgccattc-3'

followed by recombineering into DY329 to generate CL2280. torY::kan, from CL2280, was then transduced into AB2498 using standard P1 transduction methods to generate CL2341. The $u v r C 34$ allele is $\sim 60 \%$ co-transducible with torY::kan. CL2343 (SR108 uvrB5 mngB::cat) and CL2472 (SR108 uvrC34 torY::cat) were constructed by P1 transduction of uvrB5 mngB::cat and uvrC34 torY::cat from CL2337 and CL2341, respectively, into SR108. CL23 (SR108 uvrA6 zjd::Tn5) was constructed by P1 transduction of $u v r A 6$ zjd::Tn5 from HL759 into SR108. Transductants were verified by antibiotic sensitivity and sensitivity to UV irradiation at $254 \mathrm{~nm}$ where appropriate. Strains were transformed with plasmid pBR322 for interstrand crosslink incision experiments.

\section{Psoralen-UVA and Angelicin-UVA Survival Assays}

Overnight cultures grown in Davis medium supplemented with $0.4 \%$ glucose, $0.2 \%$ Casamino Acids, and $10 \mu \mathrm{g} / \mathrm{ml}$ thymine (DGCthy). Fresh overnight cultures were diluted 1:100 in DGCthy medium and grown at $37^{\circ} \mathrm{C}$ to an optical density at $600 \mathrm{~nm}$ $\left(\mathrm{OD}_{600}\right)$ of 0.3 . At this time, $10 \mu \mathrm{g} / \mathrm{ml}$ of 8 -methoxypsoralen or $20 \mu \mathrm{g} / \mathrm{ml}$ of angelicin was added to the cultures and incubation continued for 5 min before irradiation with UV-A light. Cells were irradiated using two 32-watt UVA bulbs (Sylvania) with a peak emittance of $(320 \mathrm{~nm})$ at an incident dose of $6.9 \mathrm{~J} / \mathrm{m}^{2} / \mathrm{s}$. At the times indicated, $100-\mu \mathrm{L}$ aliquots were removed from each culture and serially diluted in 10-fold increments. 
Triplicate $10-\mu$ l aliquots of each dilution were spotted onto Luria-Bertani agar plates supplemented with $10 \mu \mathrm{g} / \mathrm{ml}$ thymine (LBthy) and incubated at $37^{\circ} \mathrm{C}$. Viable colonies were counted the next day to determine the surviving fraction.

8-methoxypsoralen was purchased from Acros Organics, item 298-81-7 lot A0143457. Angelicin was purchased from Sigma-Aldrich, item A0956 lot 042M4054V. Both the NMR spectra and an HPLC profile with/without psoralen spike revealed no detectable contamination of other prosalen deriviaties in the angelicin preparation,

\section{UVC Survival Assay}

Fresh overnight cultures were diluted 1:100 in DGCthy medium and grown at $37^{\circ} \mathrm{C}$ to an $\mathrm{OD}_{600}$ of 0.4 . Ten- $\mu$ l aliquots of serial 10 -fold dilutions were plated in triplicate onto LBthy agar plates and UVC-irradiated at the indicated doses. UVC irradiation used a 15-watt germicidal lamp $(254 \mathrm{~nm})$ at an incident dose of $0.9 \mathrm{~J} / \mathrm{m}^{2} / \mathrm{s}$. Plates were incubated at $37^{\circ} \mathrm{C}$ and colonies were counted the next day to determine the surviving fraction.

\section{$\underline{\text { In vitro Plasmid Crosslinking Assay }}$}

Purified plasmid was treated with $10 \mu \mathrm{g} / \mathrm{mL}$ of 8 -methoxy-psoralen or $20 \mu \mathrm{g} / \mathrm{mL}$ of angelicin and irradiated with increasing doses of UV-A light (320 nm). Treated plasmid DNA was digested with PuvII (Fermentas) over night at 37C. Samples were electrophoresed on a $0.5 \%$ alkaline agarose gel $(30 \mathrm{mM} \mathrm{NaOH}$ and $1 \mathrm{mM}$ EDTA) at $30 \mathrm{~V}$ for $16 \mathrm{~h}$. DNA in the gels was then transferred to Hybond N+ nylon membranes (GE Healthcare) using standard Southern blotting techniques. The plasmid DNA was detected 
by probing with ${ }^{32} \mathrm{P}$-labeled pBR322 that was prepared by nick translation (Roche) using alpha ${ }^{32} \mathrm{P}-\mathrm{dCTP}>6000 \mathrm{Ci} / \mathrm{mmol}$ (Perkin-Elmer) and visualized using a Storm 840 phosphorimager (GE Biosciences) and its associated ImageQuant analysis software.

\section{$\underline{\text { In vivo Interstrand Crosslink Incision Assay }}$}

Cultures containing the plasmid pBR322 were grown overnight at $37^{\circ} \mathrm{C}$ in DGCthy medium supplemented with $100 \mu \mathrm{g} / \mathrm{ml}$ of ampicillin. A $0.2-\mathrm{ml}$ aliquot from this culture was pelleted and resuspended in 20-ml DGCthy medium without ampicillin and grown in a $37^{\circ} \mathrm{C}$ shaking water bath to an $\mathrm{OD}_{600}$ of 0.4 . At this time, cultures were exposed to $10 \mu \mathrm{g} / \mathrm{ml} 8$-methoxypsoralen for $5 \mathrm{~min}$ at $37^{\circ} \mathrm{C}$ and subsequently irradiated with $6.2 \mathrm{~kJ} / \mathrm{m}^{2} \mathrm{UV}-\mathrm{A}$ light $(320 \mathrm{~nm})$. The cells were then filtered and collected on Millipore $0.45-\mu \mathrm{m}$ general filtration membranes, resuspended in fresh, prewarmed DGCthy medium and allowed to recover at $37^{\circ} \mathrm{C}$. At the times indicated, $0.75-\mathrm{mL}$ aliquots of culture were transferred to an equal volume of ice-cold NET (100 mM NaCl, 10mM Tris [pH 8.0], $20 \mathrm{mM}$ EDTA [pH 8.0]), centrifuged for $2 \mathrm{~min}$, resuspended in 140 $\mu 1$ lysis buffer $(1 \mathrm{mg} / \mathrm{ml}$ lysozyme, $0.5 \mathrm{mg} / \mathrm{ml}$ RNaseA in $10 \mathrm{mM}$ Tris, $1 \mathrm{mM}$ EDTA [pH 8.0]), and incubated at $37^{\circ} \mathrm{C}$ for $30 \mathrm{~min}$. Ten $\mu \mathrm{l}$ of $10 \mathrm{mg} / \mathrm{ml}$ proteinase $\mathrm{K}$ and $10 \mu \mathrm{l}$ of $20 \%$ Sarkosyl were then added to the samples, and incubation continued for a further 30 min. Samples were then extracted with four volumes of phenol-chloroform, followed by four volumes of chloroform and then dialyzed against $200 \mathrm{ml}$ of $1 \mathrm{mM}$ Tris (pH 8.0), $2 \mathrm{mM}$ EDTA ( $\mathrm{pH}$ 8.0) for $45 \mathrm{~min}$ using $47-\mathrm{mm}$ Millipore $0.025-\mu \mathrm{m}$ pore disks and digested with PvuII (Fermentas) overnight at $37^{\circ}$ C. Samples were then electrophoresed on a $0.5 \%$ alkaline agarose gel $(30 \mathrm{mM} \mathrm{NaOH}$ and $1 \mathrm{mM}$ EDTA) at $30 \mathrm{~V}$ for $16 \mathrm{~h}$. DNA in 
the gels was then transferred to Hybond N+ nylon membranes (GE Healthcare) using standard Southern blotting techniques. The plasmid DNA was detected by probing by ${ }^{32} \mathrm{P}$-labeled pBR322 that was prepared using nick translation (Roche) using alpha ${ }^{32} \mathrm{P}$ dCTP >6000Ci/mmol (Perkin-Elmer) and visualized using a Storm 840 phosphorimager (GE Biosciences) and its associated ImageQuant analysis software.

The fraction of psoralen crosslinks formed at each time point was calculated as the ratio of DNA running above the linear band to the total DNA loaded, and normalized to the average of the fraction of crosslinks in untreated and preirradiated samples. Fraction of Crosslink

$\left.=\left(\mathrm{XD}_{\text {timeX }} \mathrm{X} / \mathrm{TD}_{\text {timeX }} \mathrm{X}\right)-\left(1 / 2\left(\mathrm{XD}_{\text {untreated }}+\mathrm{XD}_{\text {preirrdation }}\right) / \mathrm{TD}_{\text {untreated }}+\mathrm{TD}_{\text {preirradiation }}\right)\right)$ where $\mathrm{XD}$ represents crosslinked DNA and TD represents total DNA.

\section{RESULTS}

Irradiation with UV-C generates two predominant lesions, the cis, syn cyclobutane pyrimidine dimer and the pyrimidine 6-4-pyrimidine photoproducts in the $\operatorname{DNA}(27,28)$. Repair of these lesions in $E$ coli is known to require $u v r A, u v r B$ and $u v r C$ genes to initiate nucleotide excision repair of UV- induced DNA lesions (39). Mutants lacking any of these gene products fail to remove these lesions and are equally sensitive to UV-C irradiation (27). Consistent with earlier studies, we observed that the survival of our $u v r A, u v r B$ and $u v r C$ deletion mutants decreased at the same rate as the UV-C dose was increased, indicating that each protein contributes equally to survival following UVC-induced damage Figure 2-1A . 
We next examined the survival of these strains following psoralen-induced DNA damage. To this end, $10 \mu \mathrm{g} / \mathrm{ml} 8$-methoxypsoralen was added to growing cultures of the parental and mutant strains before they were exposed to $6.9 / \mathrm{J} / \mathrm{m} 2 / \mathrm{s}$ UV-A irradiation for increasing time periods .The fraction of cells surviving to form colonies was then determined.

In contrast to that observed in UV-C irradiation, the $u v r$ strains did not equally contribute to survival of psoralen-induced lesions (Figure 2-1B). Relative to wild type cells, $u v r A$ and $u v r B$ mutants were equally hypersensitive to psoralen-induced damage. However, the hypersensitivity of $u v r C$ mutants was significantly less than either $u v r A$ or $u v r B$ and required approximately twice as much $\mathrm{UV}-\mathrm{A}$ radiation to reduce the survival of $u v r C$ mutants to the level observed in $u v r A$ or $u v r B$ mutants. Importantly, no loss of viability was observed in wild type or $u v r A$ cultures that were treated either with UV-A irradiation alone (Figure 2-1C) or incubated with psoralen alone, indicating that the hypersensitivity and loss of viability in these cells was specifically due to the photoactivated forms of psoralen and not due to the intercalation of psoralen or UVAspecific damage. Thus, we observed that the $u v r C$ gene is less sensitive to psoraleninduced damage than either $u v r A$ or $u v r B$. 

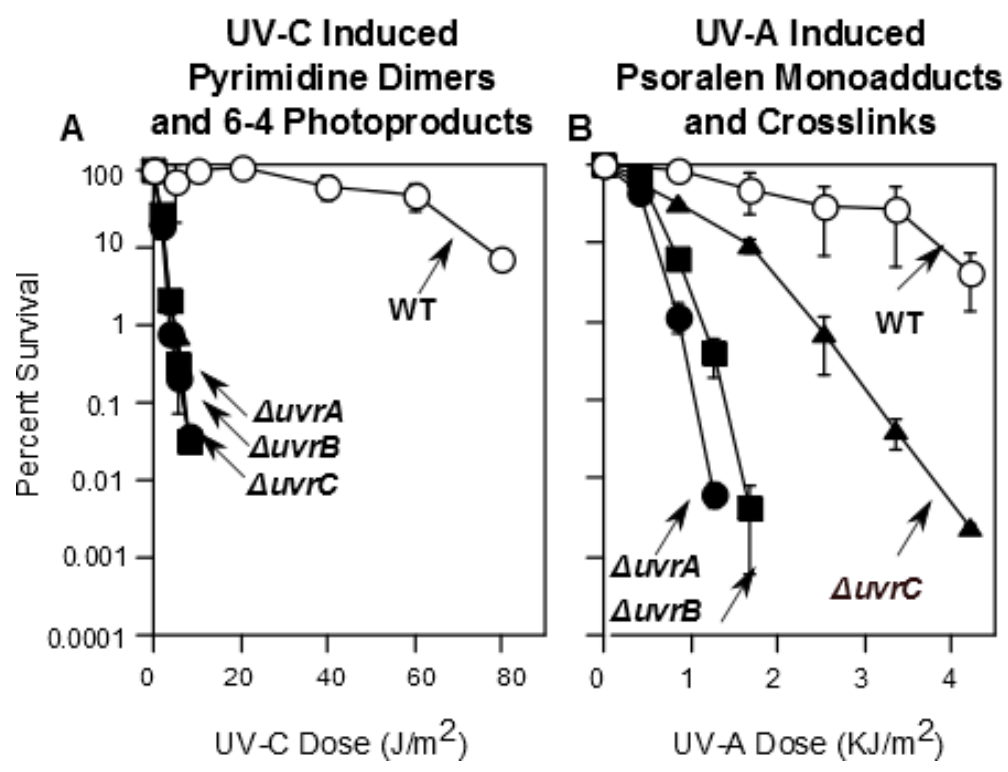

C UV-A Only No Psoralen

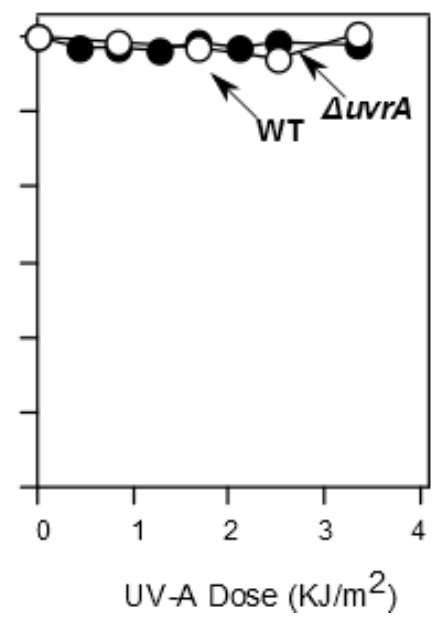

Figure 2-1 In contrast to $\mathrm{UV}$-induced damage, $u v r C$ mutants are less sensitive to psoralen-induced adducts than either $u v r A$ or $u v r B$ mutants.

The survival of cells following irriadiation with UVC light $(254 \mathrm{~nm})$ (A) or UV-A light $(340 \mathrm{~nm})$ in the presence of $10 \mu \mathrm{g} / \mathrm{ml} 8$-methoxy-psoralen (B) is plotted. The survival of cells following irradiation with UV-A light (340nm) in the absence of psoralen $(C)$ is plotted. WT (open circles), $u v r A$ (closed circles), $u v r B$ (closed square), and $u v r C$ (closed triangles).Graphs represent the average of three independent experiments. Error bars represent one standard deviation. 
These results were unexpected and contrasted with those of Lage et.al. (2010) in which they observed that $u v r B$ was markedly more hypersensitive to psoralen-induced damage than either $u v r A$ or $u v r C$ (26). One potential reason for the discrepancy between our results and those of Lage et al are the differences between our experimental conditions. Lage et al (2010) used psoralen at concentrations of $0.1 \mu \mathrm{g} / \mathrm{ml}$, and then irradiated cultures for time periods extending up to several hours on ice to achieve lethal levels of psoralen-induced damage. Since the initial goal of our study was to observe the time course of psoralen crosslink repair in living cells, the temperature changes and long exposure times were impractical. Thus we treated our strain cultures with a higher concentration of 8 -methoxypsoralen $(10 \mu \mathrm{g} / \mathrm{ml})$ similar to other studies. Allowing us to reduce our irradiation times and avoid temperature changes. A second potential reason for the differences seen in our results and those of Lage et al 2010, could be due to the difference in strain backgrounds or the specific $u v r$ alleles used in each study. The $u v r$ mutants used in the Lage et al study were direct isolates from nitrous acid-mutagenized cultures(20). Previous studies have also reported that various strains of E.coli can vary significantly in the sensitivity to DNA crosslinks $(4,20)$.

In order to test and differentiate between the possibilities, we repeated the survival assays using the strains from the Lage et al study with high 8-methoxypsoralen concentrations $(10 \mu \mathrm{g} / \mathrm{ml})$ and short UV-A exposure times. As shown in Figure 2-2A, we were able to reproduce their observations, demonstrating the extreme sensitivity of strain AB1885, containing the $u v r B 5$ mutation, to psoralen-induced damage. The results refute the idea that underlying differences between our results are due to different treatment 
conditions and suggest that $u v r B 5$ allele or strain background may be the reason for its extreme hypersensitivity. To test this hypothesis, we moved the uvrA6, uvrB5, and uvrC34 alleles in the SR108 background using standard P1 transduction to generate isogenic strains. We then repeated the experiments as before. As shown in Figure 2-2B, after moving alleles into isogenic backgrounds, hypersensitivity of the $u v r B 5$ mutant was similar of that $u v r A 6$ allele. These results indicate that extreme hypersensitivity of the strain AB1185 is likely due to secondary mutations or differences between the various backgrounds. However, consistent with the initial observation in Figure 1B, the hypersensitivity of $u v r C 34$ mutant was more modest than that of either $u v r A$ or $u v r B$ in all strains examined, arguing that the loss of $u v r C$ is not as lethal as the loss of $u v r A$ or $u v r B$ when psoralen-induced damage is present in the cell. 

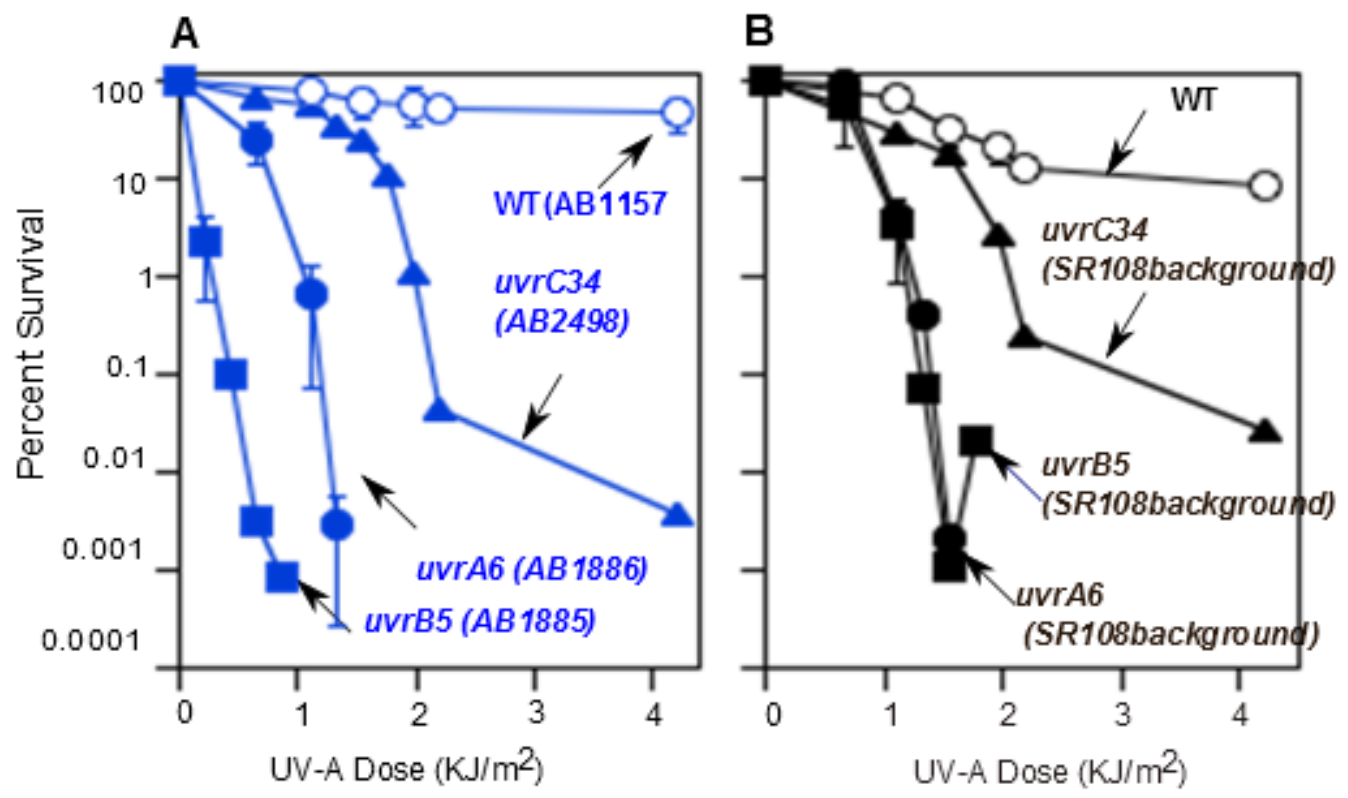

Figure 2-2 Isogenic backgrounds are important when comparing sensitivities of the NER mutants to psoralen

A) The survival of $u v r A 6, u v r B 5$ and $u v r C 34$ mutants following irradiation UV-A (340nm) light in the presence of $10 \mu \mathrm{g} / \mathrm{ml} 8$-methoxy-psoralen is plotted before (A) and after (B) moving the alleles into isogenic backgrounds. (A) AB1157 wild type strain, uvrA6 in strain AB1886 (closed blue circles), $u v r B 5$ in strain AB1885 (blue square), $u v r C 34$ in strain AB1884 (B) SR108 parental (open blue circles), uvrA6 in SR108 (closed black circles), $u v r B 5$ in SR108 (black square closed), $u v r C 34$ in SR108 (closed triangles) Graphs represent the average of three independent experiments. Error bars represent one standard deviation. 
Although the UvrABC excision is thought to function as a complex $(40,41)$, the survival assays indicated that $u v r C$ was less sensitive to psoralen-induced damage than $u v r A$ or $u v r B$. Given that UvrA and $\mathrm{UvrB}$ act in the initial recognition step of the NER pathway, while $u v r C$ functions as the nuclease, I hypothesized that an alternative endonuclease might be participating in the repair of the psoralen-induced damage. Cho

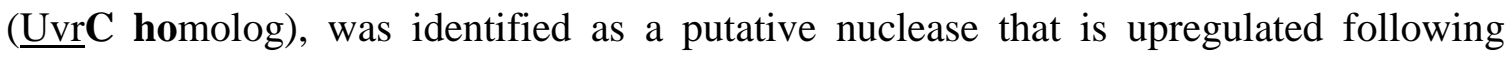
DNA damage (30) . Subsequent biochemical studies showed that in the presence of the UvrABC endonuclease, Cho was able to make a 3' incision two bases further away than UvrC and that this activity could act on a variety of lesions in vitro. However, its function in vivo remains unclear as cho mutants are not sensitive to UV or other forms of damage that have been examined (30).To test whether Cho was responsible for the increased resistance of $u v r C$ to psoralen-induced damage, we characterized cho mutants and cho $u v r C$ double mutants for their ability to survive psoralen-induced damage. As shown in Figure 3A, cho mutants were only modestly sensitive to the psoralen-induced damage, relative to other $u v r$ mutants (Figure 2-3A). Interestingly however, the absence of Cho increased the hypersensitivity of $u v r C$ mutants to a level that was similar to $u v r A$ and $u v r B$ mutants (Figure 2-3A). The observation indicates that Cho is responsible for the decreased sensitivity of $u v r C$ mutants in the presence of psoralen-induced lesions. 


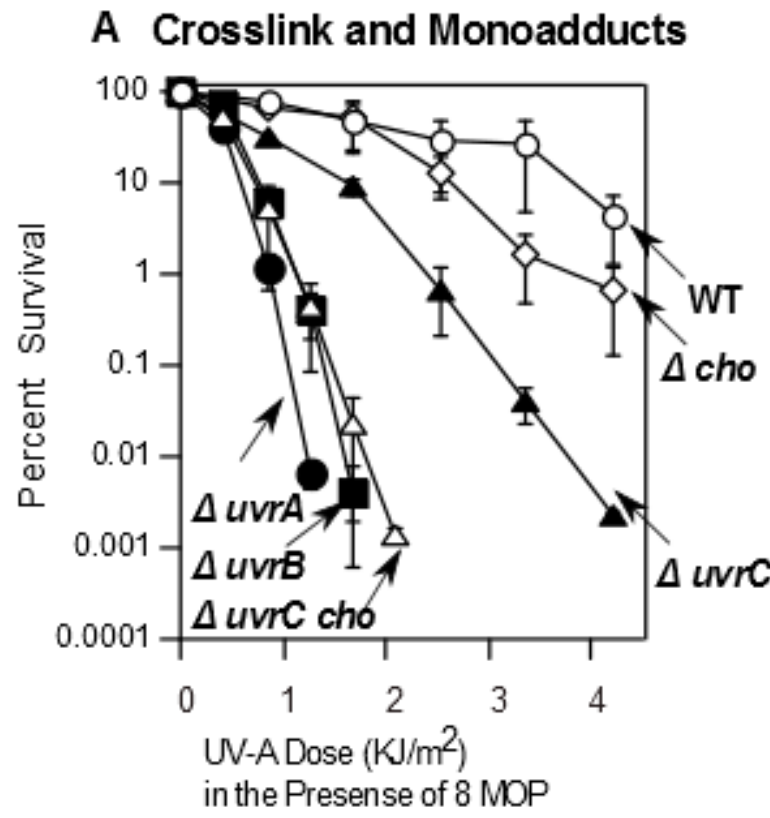

B Monoadducts

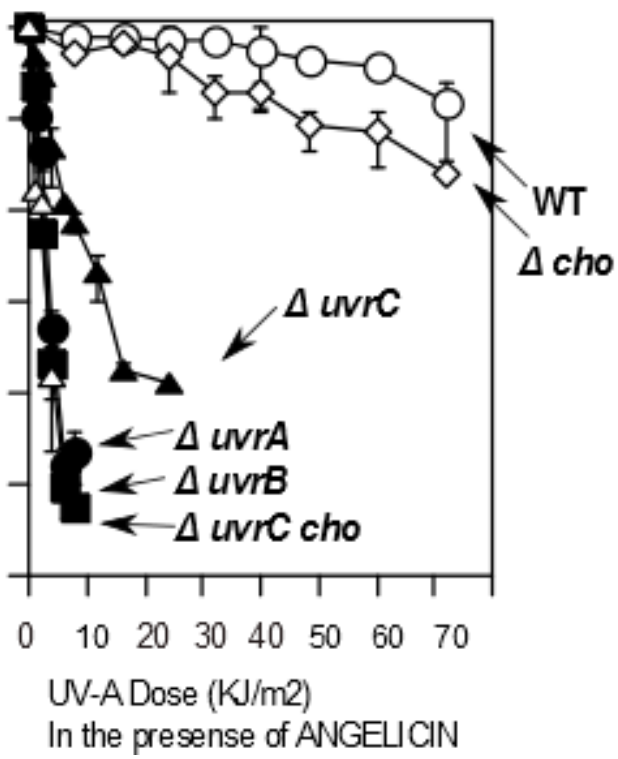

Figure 2-3 Cho accounts for the reduced sensitivity of $\mathrm{uvrC}$ mutants and is required specifically in the presence of interstrand DNA crosslinks. A) The survival of cells following irradiation with increasing doses of UV-A $(340 \mathrm{~nm})$ light in the presence of $10 \mu \mathrm{g} / \mathrm{ml}$ 8-methoxy-psoralen (A) or B) $20 \mu \mathrm{g} / \mathrm{ml}$ of angelicin is plotted. WT (open circles), $u v r A$ (closed circles), $u v r B$ (closed square), $u v r C$ (closed triangles), cho (open diamonds), and $u v r C$ cho (Open triangles)

Graphs represent the average of the three or more independent experiments. Error bars represent one standard deviation. 
8-methoxypsoralen is capable of creating both monoadducts and interstrand crosslinks with exposure to the UV-A light $(1,23)$. One possible explanation for the increased sensitivity of Cho in the absence of $u v r C$ is that Cho is required to act with UvrC on only one of these two classes of lesions. To test this idea, the experiments were repeated using angelicin in place of the 8-methoxypsoralen. Angelicin shares a similar structure to that of 8-methoxypsoralen, but is thought to only be capable of forming mono adducts due to its angular structure. In contrast to 8-methoxypsoralen, in the presence of angelicin, the relative hypersensitivity of the $u v r C$ mutant increased to a level that approached that of the $u v r A$ and $u v r B$ mutants (Figure 2-3B). The slight resistance that remained between $u v r C$ and the $u v r A$ and $u v r B$ mutant survival is likely to be due a low level of interstrand DNA crosslinks that still form in the angelicin-treated samples (Figure 2-4B). Although angelicin is reported to only be capable of forming monoadducts, we observed that our angelicin-treated DNA could form interstrand DNA crosslinks, although at a rate that was orders of magnitude less efficient than that of 8methoxypsoralen (Compare Figure 2-4 A and B). 

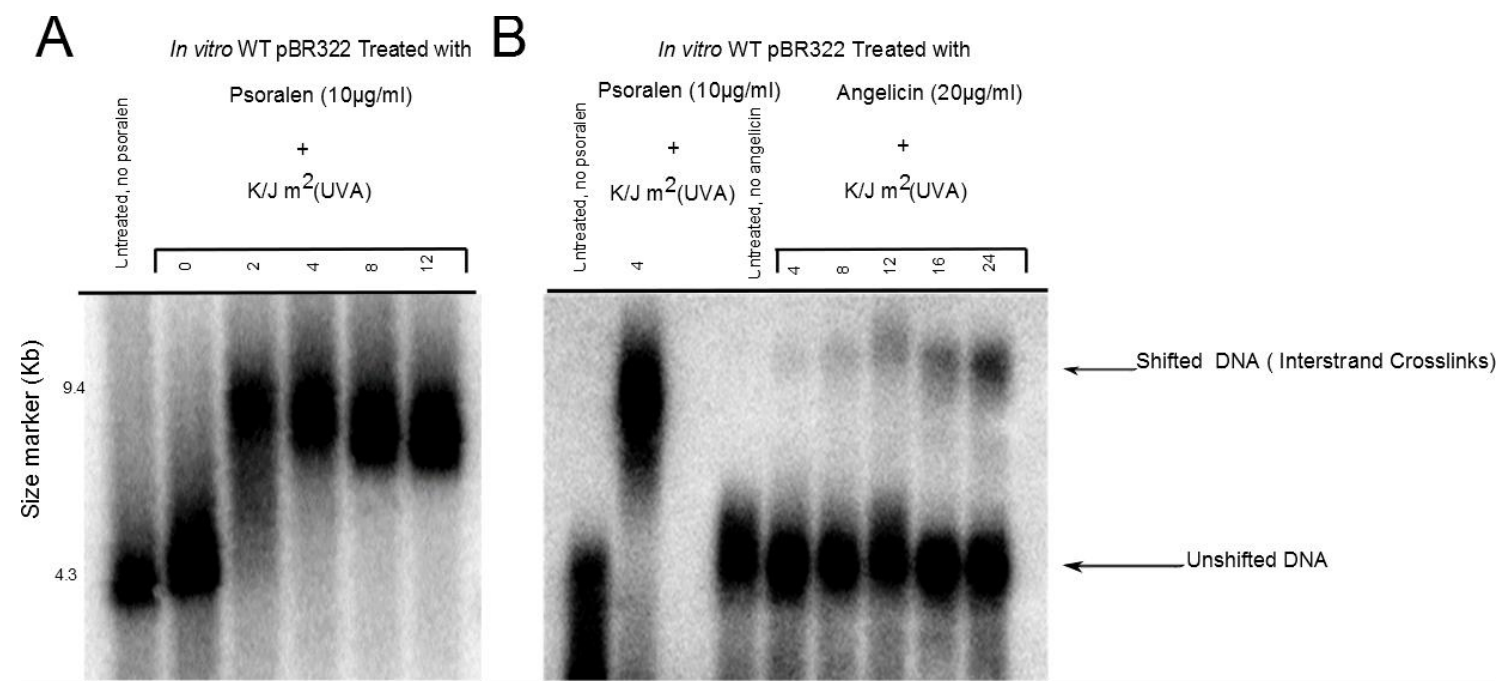

Figure 2-4 Purified plasmid treated with angelicin UV-A light forms minor product of DNA interstrand crosslinks.

A) Purified plasmid pBR322, was treated with $10 \mu \mathrm{g} / \mathrm{mL} 8$-methoxy-psoralen or B) $20 \mu \mathrm{g} / \mathrm{mL}$ angelicin and irradiated with UV-A (340 nm) light for increasing doses. DNA was restricted with PvuII and analyzed by southern analysis following alkali-agarose gel electrophoresis using pBR322 as a probe to determine the amount of DNA interstrand crosslinks present. 

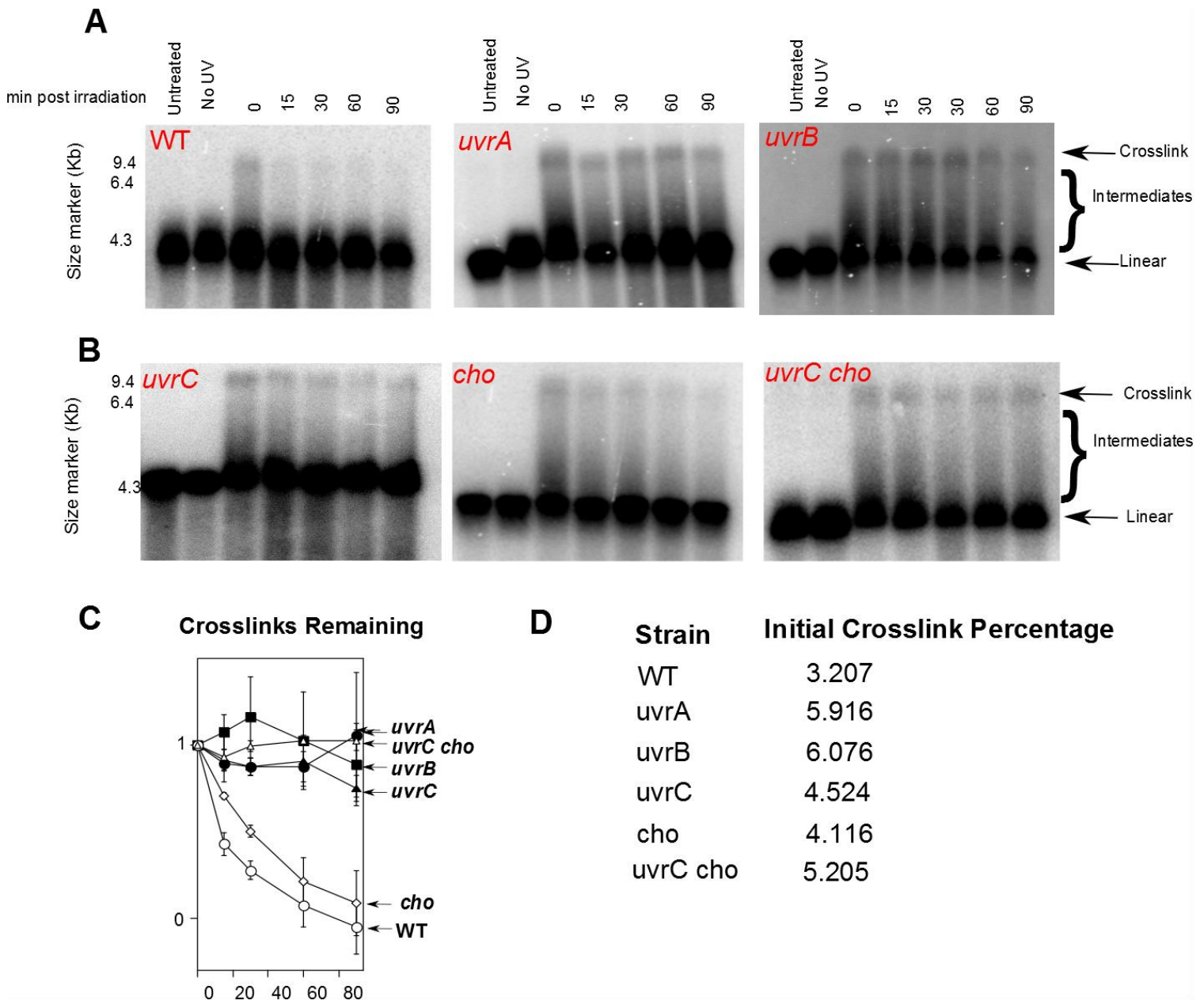

$\begin{array}{ll}\text { WT } & 3.207 \\ \text { uvrA } & 5.916 \\ \text { uvrB } & 6.076 \\ \text { uvrC } & 4.524 \\ \text { cho } & 4.116 \\ \text { uvrC cho } & 5.205\end{array}$

Figure 2-5 UvrC but not Cho is required for the initial incision of the crosslink in vivo.

A) Cultures containing the plasmid, pBR322, were irradiated with UV-A (340nm) light for 15 $\mathrm{min}$ in the presence of $10 \mu \mathrm{g} / \mathrm{ml}$ 8-methoxy-psoralen and allowed to recover. At the indicated time points, total genomic DNA was purified, restricted with PvuII, and analyzed by southern analysis following alkali-agarose gel electrophoresis using pBR322 as a probe to determine the amount of DNA interstrand crosslinks present in the plasmid DNA over the recovery period. A representative gel for WT $u v r A, u v r B, u v r C$, cho, and $u v r C$ cho is shown.

B) The relative amount of crosslinks remaining in the plasmid DNA over time is plotted, as normalized to the amount of noncrosslinked plasmid DNA. Band intensities for the DNA crosslinked and uncrosslinked fragments at each time point were Quantified using imageQuant software. Fraction of crosslinks at each time point were determined by calculating the ratio of the DNA crosslink band to linear plasmid. WT (open circles), uvrA (closed circles), uvrB (closed square), $u v r C$ (closed triangles), cho (open diamonds), and $u v r C$ cho (Open triangles). Plots represent the average of two independent experiments. Error bars represent the standard error of the mean. 
Based on the survival assays, Cho appears to contribute to the repair of DNA interstrand crosslinks. To examine whether the absence of Cho affects the ability to initiate repair of the crosslinks in vivo, we compared each mutant's ability to incise interstrand crosslinks. To this end, I treated cultures containing the plasmid pBR322 with 8-methyoxypsoralen and UV-A light and then allowed them to recover over a period of time. At various time intervals, aliquots of the culture were taken, and the genomic and plasmid DNA was purified and restricted with PvuII which linearizes the plasmid. The DNA was then electrophoresed in a denaturing agarose gel and plasmid DNA was detected by southern analysis. Under denaturing conditions, DNA molecules that contain interstrand crosslinks are prevented from separating and can be detected due to their slower migration pattern relative to linear strands in alkali gels. In wild type cultures immediately following irradiation, approximately $3.2 \%$ of the plasmid DNA contained an interstrand DNA crosslink (Figure 2-4A and C). Over the 90 minute recovery period, the fraction of DNA migrating in the crosslink region of the gel decreased to approximately $0.57 \%$, which we interpret to reflect incision of the crosslinks over time. In cultures of $u v r A$, $u v r B$ mutants, $5.9 \%$ and $6.0 \%$ of the plasmid molecules contained DNA interstrand crosslinks immediately after irradiation. However, in these cultures, the crosslinks remained throughout the recovery period and no decrease in the shifted DNA band was observed, indicating that these cultures are impaired in their ability to make the initial incision (Figure 2-4A and 2-4C). When I examined cultures of $u v r C$, I observed that the crosslinks formed and persisted similar to that seen in $u v r A$ and $u v r B$ cultures (Figure 24B and 2-4C). Thus although the $u v r C$ mutant is markedly less sensitive, by this assay, it 
appears to be as defective in making the initial incision as either $u v r A$ or $u v r B$ mutants. In contrast, crosslinks were incised in cho mutants at a rate that was similar to wild type cultures, as indicated by the decrease in the intensity of the crossed link DNA band. In the $u v r C$ cho double mutant, the initial incision was impaired to a similar extent as in $u v r C$ mutants. We interpret these results to suggest that although Cho contributes to survival in the presence of interstrand DNA crosslinks, it is not required for the initial incision the DNA interstrand crosslinks in vivo.

\section{DISCUSSION}

In this chapter, I investigated the role of nucleotide excision repair proteins in repairing psoralen-induced DNA damage. I found that not all the NER subunits contribute equally to the survival of psoralen-induced damage. Notably, mutants lacking the endonucleotic subunit UvrC are less sensitive to psoralen-induced damage than mutants lacking the recognition proteins UvrA or UvrB. The increased resistance of $u v r C$ was found to depend upon Cho, a secondary UvrABC-dependent endonuclease that is strongly induced after DNA damage (30).

The observation that Cho inactivation reduced the partially sensitive $u v r C$ mutant to a level similar to that of $u v r A$ and $u v r B$ mutants, suggested that Cho is only required to participate in a subset of the psoralen-induced repair events. Since psoralen plus UV-A irradiation generates two classes or subsets of DNA lesions, one possibility is that Cho functions with UvrABC to repair psoralen interstrand crosslinks, but not monoadducts. Using a psoralen-derivative that predominantly forms monoadducts, I found that Cho was specifically required for survival in the presence of DNA interstrand crosslinks, but did 
not contribute significantly to the repair of monoadducts. Interestingly, although Cho contributes to survival in the presence of crosslinks, its absence did not affect the cell's ability to make the initial incision on plasmids in vitro, suggesting that Cho operates later in the repair process or in only a subset of crosslink repair events.

I consider three possible scenarios that Cho function is required in the cell for repairing DNA interstrand crosslinks. One possibility is that Cho is required for repair of the interstrand crosslinks that block replication is blocked or those occurring in the global genome overall (Figure 2-5). Several studies based upon experiments using mammalian cell extracts have proposed that the repair of interstrand DNA crosslinks can occur through replication dependent and replication independent pathways $(25,51,52)$. Fanconi anemia is a rare inherited disease that predisposes humans to cancer, involving more than 15 complementation groups, which renders cells highly sensitive to DNA interstrand crosslinks. Recent studies have suggested that the Fanconi anemia defect is specifically related to the repair of crosslinks encountered by the replication fork (51). In addition, the Fanconi anemia proteins FANCD2 and SLX4/FANCP interact with the 3' endonuclease of the mammalian nucleotide excision repair complex, XPF-ERCC1, to affect repair. The participation of XPF-ECRCC1 is independent from its role in nucleotide excision repair, as the remaining subunits of the NER complex are not required (51) (24). By analogy in E. coli, it is possible that the alternative nuclease, Cho, functions specifically at the replication fork to effect repair. In vitro, incision of DNA interstrand crosslinks occurs more efficiently on underwound superhelical substrates, perhaps suggesting that superhelicity differences between the DNA at replication forks 
and the overall chromosome necessitate a role for Cho to act with UvrC in some cases (31). A role in replication-coupled repair would also be consistent with the observation that Cho has only a minor effect on the rate of crosslink incisions (Fig 2-5). Similar to the case with UV-induced damage, since the proportion of lesions requiring replicationspecific repair events is quite small, mutants defective in replication-coupled repair would be expected to appear repair proficient (10). However, other observations do not support such a role for Cho. Defects in replication-coupled repair typically have severe effects on cell survival in both prokaryotes and eukaryotes, even when only low levels of damage are present (8-11).Yet the absence of Cho, by itself, does not have a large effect on cell survival.

A second possible role for Cho is that it acts as a secondary nuclease for the nucleotide excision repair complex that increases the efficiency of incision for some forms of bulky adducts (Figure2- 6). In vitro, the incision of the interstrand crosslinks by the nucleotide excision repair complex is influenced by the sequence context with preferential incisions occurring when the strands are GC enriched 5' and 3 ' to the adducted bases $(21,38)$. The longer excision patch resulting from Cho incision may enhance incision at poorly recognized or bulky lesions that cause problems for the core UvrABC exinuclease complex. Such a function could be consistent with both the survival we observe. Cho, along with UvrA and UvrB, is upregulated following DNA damage (12). However, UvrC is the only subunit that is not upregulated by DNA damage. If Cho did function to increase the efficiency of excision of psoralen damage, it would be expected to have a more significant effect on survival when high levels of DNA damage 
are present, and less of an effect at lower levels of damage, as seen in our survival data. However, one might still expect to see that the rate of incision is affected in the absence of Cho, and this did not appear to be the case (Figure 2-5).

A third possibility is that Cho may function in a later step in the crosslink repair pathway, after the initial incision (Figure 2-7). In vitro, UvrABC exinuclease incises psoralen interstrand crosslinks on the strand containing the furan moiety of the psoralen molecule while leaving the strand containing the pyrone moiety intact $(42,43,47-49)$. Replication independent repair models propose that following incision, either recombination or translesion synthesis generates a bulky three stranded structure, with the oligo containing the adduct. It is possible that Cho is required to make this second incision on the pyrone side strand, leading to the second round of repair. Cho protein is known to incise bulky substrates more efficiently than $\mathrm{UvrC}$ and Cho acting in this manner would be consistent with results showing that it remains proficient in making the initial incision (Fig 2-4) (30). An inability to carry out the second round of repair could also be less lethal than mutants unable to initiate repair, if alternative pathways, such as translesion synthesis or recombination, were able to compensate and act on the incised substrates when Cho is absent. Considering the angelicin survival data, and the psoralen in vivo incision results, I favor the third model as most likely the role of Cho in repairing DNA interstrand crosslinks. All our results are consistent with the model that Cho is required for the second incision step of the repair process, but not the first step. However, more experiments are required to confirm that Cho is responsible for the second incision of the repair process. 

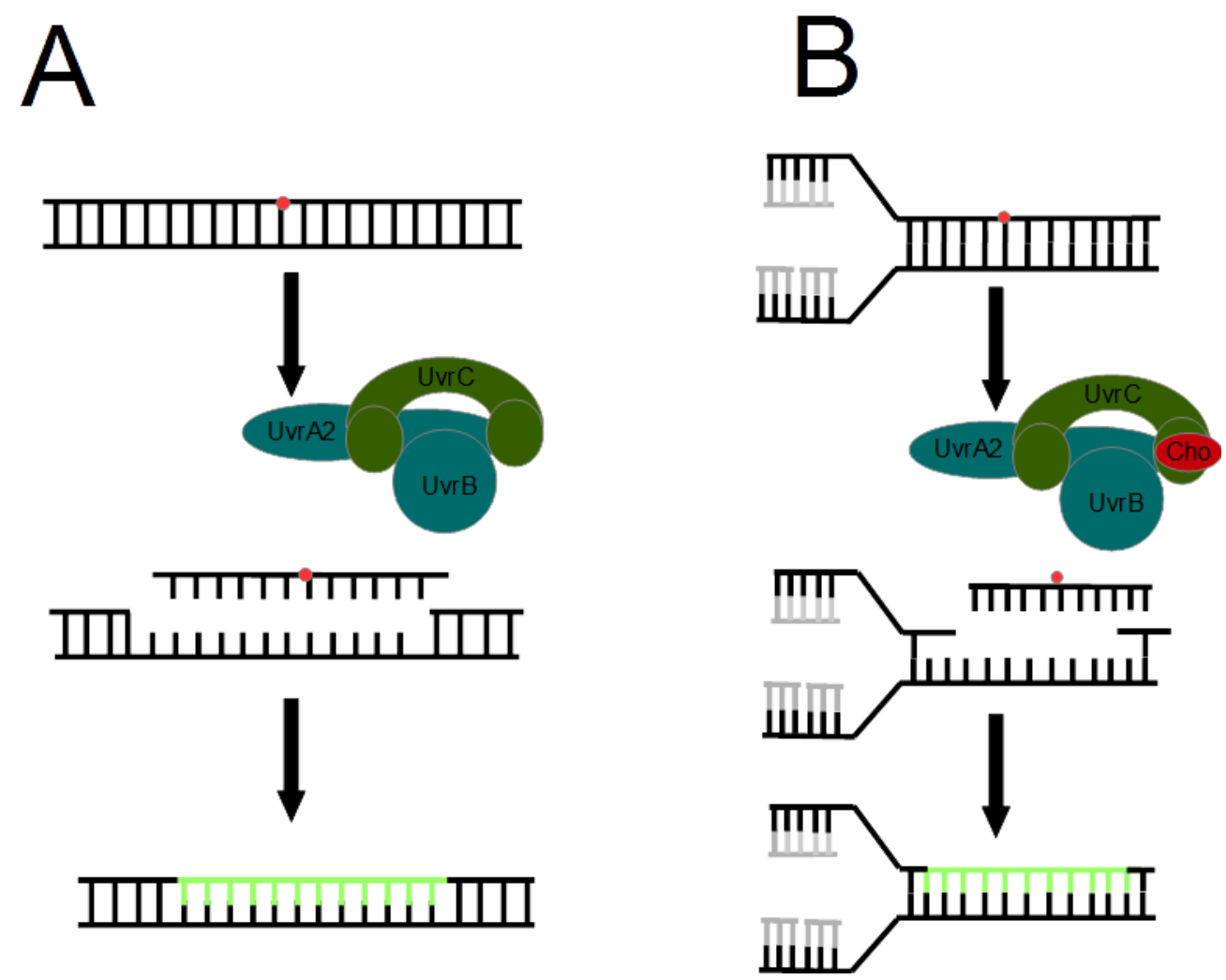

Figure 2-6: Model 1, Cho is required for repair of psoralen-induced lesions in a replication dependent manner. A) Global repair pathway B) Cho protein is involved in repairing psoralen-induced lesions only at replication fork arrest and assist in making incision in addition to UvrC. 


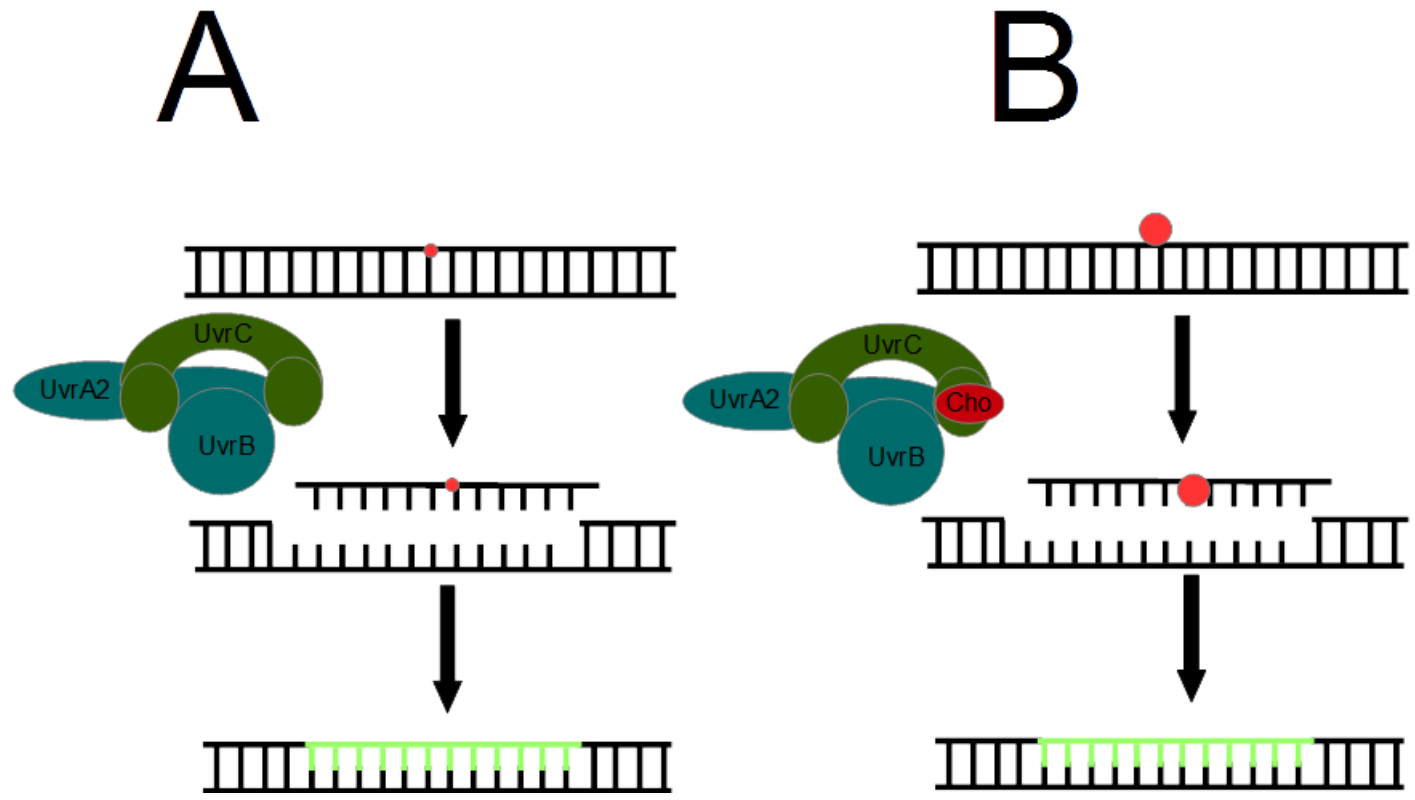

Figure 2-7: Model 2, Cho is required to increase the efficiency of psoralen-induced lesions in addition to UvrC. A) Main NER proteins repairing lesions. B) Cho is required to increase efficiency of incision rate in the presence of psoralen-induced lesions (bulkier lesions). 


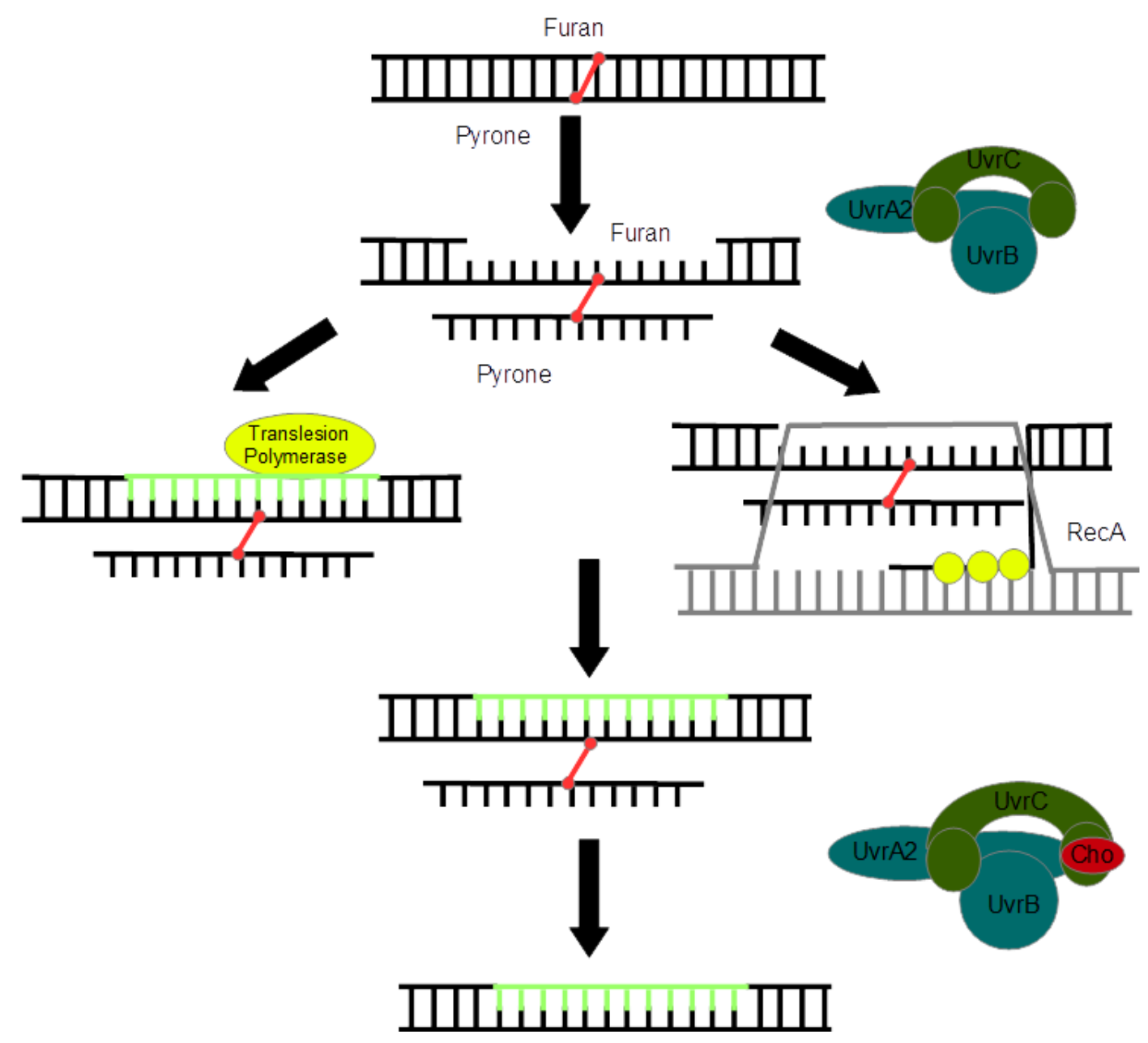

Figure 2-8: Model 3, Cho is responsible for the second incision step of the repair process at pyrone side of psoralen-induced lesions after recombination or translesion synthesis. Cho is responsible for the second incision followed recombination or translesion synthesis. In order for cells to completely remove the lesion, a second incision need to occur after first incision step. Cho makes the incision on pyrone side, while other main NER proteins are required to make the first incision on furan side. 


\section{REFERENCES}

1. Ashwood-Smith, M. J., and E. Grant. 1977. Conversion of psoralen DNA monoadducts in E. coli to interstrand DNA cross links by near UV light (320-360 $\mathrm{nm}$ ): Inability of angelicin to form cross links, in vivo. Experientia 33:384-386.

2. Berardini, M., W. Mackay, and E. L. Loechler. 1997. Evidence for a Recombination-Independent Pathway for the Repair of DNA Interstrand CrossLinks Based on a Site-Specific Study with Nitrogen Mustard $\uparrow$. Biochemistry 36:3506-3513.

3. Boyce, R., and P. Howard-Flanders. 1964. Genetic control of DNA breakdown and repair inE. coli K-12 treated with mitomycin $\mathrm{C}$ or ultraviolet light. Zeitschrift für Vererbungslehre 95:345-350.

4. Bridges, B. A. 1984. Further characterization of repair of 8-methoxypsoralen crosslinks in UV-excision-defective Escherichia coli. Mutation Research/DNA Repair Reports 132:153-160.

5. Bridges, B. A., and M. Stannard. 1982. A new pathway for repair of crosslinkable 8-methoxypsoralen mono-adducts in Uvr- strains of Escherichia coli. Mutation Research/Fundamental and Molecular Mechanisms of Mutagenesis 92:9-14.

6. Cole, R. S. 1973. Repair of DNA Containing Interstrand Crosslinks in Escherichia coli: Sequential Excision and Recombination. Proceedings of the National Academy of Sciences 70:1064-1068.

7. Cole, R. S., D. Levitan, and R. R. Sinden. 1976. Removal of psoralen interstrand cross-links from DNA of Escherichia coli: Mechanism and genetic control. Journal of Molecular Biology 103:39-59.

8. Courcelle, C. T., J. J. Belle, and J. Courcelle. 2005. Nucleotide Excision Repair or Polymerase V-Mediated Lesion Bypass Can Act To Restore UV-Arrested Replication Forks in Escherichia coli. Journal of Bacteriology 187:6953-6961.

9. Courcelle, J., C. Carswell-Crumpton, and P. C. Hanawalt. 1997. recF and recR are required for the resumption of replication at DNA replication forks in Escherichia coli. Proceedings of the National Academy of Sciences 94:37143719.

10. Courcelle, J., D. J. Crowley, and P. C. Hanawalt. 1999. Recovery of DNA replication in UV-irradiated Escherichia coli requires both excision repair and recF protein function. J Bacteriol 181:916-922.

11. Courcelle, J., J. Donaldson, K. Chow, and C. Courcelle. 2003. DNA damageinduced replication fork regression and processing in Escherichia coli. Science (New York) 299:1064-1067.

12. Courcelle, J., A. Khodursky, B. Peter, P. O. Brown, and P. C. Hanawalt. 2001. Comparative Gene Expression Profiles Following UV Exposure in WildType and SOS-Deficient Escherichia coli. Genetics 158:41-64.

13. Cupido, M., and B. A. Bridges. 1985. Uvr-independent repair of 8methoxypsoralen crosslinks in Escherichia coli: Evidence for a recombinational process. Mutation Research/DNA Repair Reports 146:135-141.

14. Dewitt, S. K., and E. A. Adelberg. 1962. The Occurrence of a Genetic 
Transposition in a Strain of Escherichia Coli. Genetics 47:577-585.

15. Dronkert, M. L. G., and R. Kanaar. 2001. Repair of DNA interstrand crosslinks. Mutation Research/DNA Repair 486:217-247.

16. Gupta, A. K., and T. F. Anderson. 1987. Psoralen photochemotherapy. Journal of the American Academy of Dermatology 17:703-734.

17. Hearst, J. E. 1989. Photochemistry of the psoralens. Chemical Research in Toxicology 2:69-75.

18. Hearst, J. E., S. T. Isaacs, D. Kanne, H. Rapoport, and K. Straub. 1984. The reaction of the psoralens with deoxyribonucleic acid. Quarterly Reviews of Biophysics 17:1-44.

19. Howard-Flanders, P., R. P. Boyce, and L. Theriot. 1966. THREE LOCI IN ESCHERICHIA COLI K-12 THAT CONTROL THE EXCISION OF PYRIMIDINE DIMERS AND CERTAIN OTHER MUTAGEN PRODUCTS FROM DNA. Genetics 53:1119-1136.

20. Howard-Flanders, P., and L. Theriot. 1966. Mutants of Escherichia coli K-12 defective in DNA repair and in genetic recombination. Genetics 53:1137-1150.

21. Jones, B. K., and A. T. Yeung. 1990. DNA base composition determines the specificity of UvrABC endonuclease incision of a psoralen cross-link. J Biol Chem 265:3489-3496.

22. Kelly Jr, E. W., and H. Pinkus. 1955. Local Application of 8-Methoxypsoralen in Vitiligo1. The Journal of Investigative Dermatology 25:453-456.

23. Kitamura, N., S. Kohtani, and R. Nakagaki. 2005. Molecular aspects of furocoumarin reactions: Photophysics, photochemistry, photobiology, and structural analysis. Journal of Photochemistry and Photobiology C: Photochemistry Reviews 6:168-185.

24. Klein Douwel, D., Rick A. C. M. Boonen, David T. Long, Anna A. Szypowska, M. Räschle, Johannes C. Walter, and P. Knipscheer. 2014. XPFERCC1 Acts in Unhooking DNA Interstrand Crosslinks in Cooperation with FANCD2 and FANCP/SLX4. Molecular Cell 54:460-471.

25. Knipscheer, P., M. Raschle, A. Smogorzewska, M. Enoiu, T. V. Ho, O. D. Scharer, S. J. Elledge, and J. C. Walter. 2009. The Fanconi anemia pathway promotes replication-dependent DNA interstrand cross-link repair. Science 326:1698-1701.

26. Lage, C., S. R. F. Gonçalves, L. L. Souza, M. d. Pádula, and A. C. Leitão. 2010. Differential survival of Escherichia coli uvrA, uvrB, and uvrC mutants to psoralen plus UV-A (PUVA): Evidence for uncoupled action of nucleotide excision repair to process DNA adducts. Journal of Photochemistry and Photobiology B: Biology 98:40-47.

27. Mitchell, D. L., C. A. Haipek, and J. M. Clarkson. 1985. (6-4)Photoproducts are removed from the DNA of UV-irradiated mammalian cells more efficiently than cyclobutane pyrimidine dimers. Mutat Res 143:109-112.

28. Mitchell, D. L., and R. S. Nairn. 1989. The biology of the (6-4) photoproduct. Photochem Photobiol 49:805-819.

29. Moolenaar, G. F., R. S. Uiterkamp, D. A. Zwijnenburg, and N. Goosen. 1998. The C-terminal region of the Escherichia coli UvrC protein, which is homologous 
to the C-terminal region of the human ERCC1 protein, is involved in DNA binding and 5'-incision. Nucleic Acids Res 26:462-468.

30. Moolenaar, G. F., S. van Rossum-Fikkert, M. van Kesteren, and N. Goosen. 2002. Cho, a second endonuclease involved in Escherichia coli nucleotide excision repair. Proceedings of the National Academy of Sciences 99:1467-1472.

31. Munn, M. M., and W. D. Rupp. 1991. Interaction of the UvrABC endonuclease with DNA containing a psoralen monoadduct or cross-link. Differential effects of superhelical density and comparison of preincision complexes. J Biol Chem 266:24748-24756.

32. Newburger, A. E. 1990. Carcinogenesis - a comprehensive study: Skin tumors: experimental and clinical aspects. Archives of Dermatology 126:261-261.

33. Newton, K. N., C. T. Courcelle, and J. Courcelle. 2012. UvrD Participation in Nucleotide Excision Repair Is Required for the Recovery of DNA Synthesis following UV-Induced Damage in Escherichia coli. J Nucleic Acids 271453:27.

34. Oh, E. Y., L. Claassen, S. Thiagalingam, S. Mazur, and L. Grossman. 1989. ATPase activity of the UvrA and UvrAB protein complexes of the Escherichia coli UvrABC endonuclease. Nucleic Acids Res 17:4145-4159.

35. Oh, E. Y., and L. Grossman. 1989. Characterization of the helicase activity of the Escherichia coli UvrAB protein complex. J Biol Chem 264:1336-1343.

36. Parrish, J. A., T. B. Fitzpatrick, L. Tanenbaum, and M. A. Pathak. 1974. Photochemotherapy of Psoriasis with Oral Methoxsalen and Longwave Ultraviolet Light. New England Journal of Medicine 291:1207-1211.

37. Parrish, J. A., R. S. Stern, M. A. Pathak, and T. B. Fitzpatrick. 1982. Photochemotherapy of Skin Diseases, p. 595-623. In J. Regan and J. Parrish (ed.), The Science of Photomedicine. Springer US.

38. Ramaswamy, M., and A. T. Yeung. 1994. Sequence-specific interactions of UvrABC endonuclease with psoralen interstrand cross-links. Journal of Biological Chemistry 269:485-492.

39. Sancar, A. 1996. DNA excision repair. Annu Rev Biochem 65:43-81.

40. Sancar, A., and W. D. Rupp. 1983. A novel repair enzyme: UVRABC excision nuclease of Escherichia coli cuts a DNA strand on both sides of the damaged region. Cell 33:249-260.

41. Sancar, A., and M.-s. Tang. 1993. NUCLEOTIDE EXCISION REPAIR. Photochemistry and Photobiology 57:905-921.

42. Sladek, F. M., A. Melian, and P. Howard-Flanders. 1989. Incision by UvrABC excinuclease is a step in the path to mutagenesis by psoralen crosslinks in Escherichia coli. Proc Natl Acad Sci U S A 86:3982-3986.

43. Sladek, F. M., M. M. Munn, W. D. Rupp, and P. Howard-Flanders. 1989. In vitro repair of psoralen-DNA cross-links by RecA, UvrABC, and the 5'exonuclease of DNA polymerase I. Journal of Biological Chemistry 264:67556765.

44. Tessman, J. W., S. T. Isaacs, and J. E. Hearst. 1985. Photochemistry of the furan-side 8-methoxypsoralen-thymidine monoadduct inside the DNA helix. Conversion to diadduct and to pyrone-side monoadduct. Biochemistry 24:16691676. 
45. Truglio, J. J., D. L. Croteau, B. Van Houten, and C. Kisker. 2006. Prokaryotic nucleotide excision repair: the UvrABC system. Chem Rev 106:233-252.

46. Van Houten, B. 1990. Nucleotide excision repair in Escherichia coli. Microbiol Rev 54:18-51.

47. Van Houten, B., H. Gamper, J. E. Hearst, and A. Sancar. 1988. Analysis of sequential steps of nucleotide excision repair in Escherichia coli using synthetic substrates containing single psoralen adducts. Journal of Biological Chemistry 263:16553-16560.

48. Van Houten, B., H. Gamper, J. E. Hearst, and A. Sancar. 1986. Construction of DNA substrates modified with psoralen at a unique site and study of the action mechanism of $\mathrm{ABC}$ excinuclease on these uniformly modified substrates. Journal of Biological Chemistry 261:14135-14141.

49. Van Houten, B., H. Gamper, S. R. Holbrook, J. E. Hearst, and A. Sancar. 1986. Action mechanism of ABC excision nuclease on a DNA substrate containing a psoralen crosslink at a defined position. Proceedings of the National Academy of Sciences 83:8077-8081.

50. Verhoeven, E. E., M. van Kesteren, J. J. Turner, G. A. van der Marel, J. H. van Boom, G. F. Moolenaar, and N. Goosen. 2002. The C-terminal region of Escherichia coli UvrC contributes to the flexibility of the UvrABC nucleotide excision repair system. Nucleic Acids Res 30:2492-2500.

51. Williams, H. L., M. E. Gottesman, and J. Gautier. 2013. The differences between ICL repair during and outside of S phase. Trends Biochem Sci 38:386393.

52. Williams, H. L., M. E. Gottesman, and J. Gautier. 2012. Replicationindependent repair of DNA interstrand crosslinks. Mol Cell 47:140-147.

53. Yu, D., H. M. Ellis, E. C. Lee, N. A. Jenkins, N. G. Copeland, and D. L. Court. 2000. An efficient recombination system for chromosome engineering in Escherichia coli. Proc Natl Acad Sci U S A 97:5978-5983. 


\title{
CHAPTER III
}

\section{ELEMENTS OF RECOMBINATION PATHWAY AND TRANSLESION POLYMERASES ARE REQUIRED FOR THE REPAIR OF DNA INTERSTRAND CROSSLINKS}

\begin{abstract}
Agents forming DNA interstrand crosslinks are highly toxic and widely used in the treatment of hyperplastic disease. For these reasons the mechanism by which cells repair these lesions is of intense interest. Most models propose that repair is initiated by the nucleotide excision repair pathway, and coupled with either recombination pathways, translesion synthesis pathways or both. However, following incision, these models remain highly speculative, and the role of recombination and translesion synthesis in the repair of interstrand crosslinks still remains unclear. In order to further characterize how recombination proteins and translesion synthesis polymerases contribute to the repair of interstrand DNA crosslinks, I examined how these gene products contribute to the survival of psoralen damage. I observed that both $\operatorname{rec} B C$ and $\operatorname{rec} F$ mutants were hypersensitive to psoralen-induced lesions; however neither mutant was as sensitive as a recA mutant. With respect to translesion synthesis, I found that Polymerase $\mathrm{V}$ was the only translesion polymerase that contributes to survival of psoralen damage. I discuss these results in relation to both prokaryotic and mammalian models for crosslink repair.
\end{abstract}

\section{INTRODUCTION}

DNA interstrand crosslinks are a particularly lethal form of DNA damage that represents an absolute block to replication and transcription. A number of chemicals forming DNA crosslinks have proven to be highly toxic in nature, uniquely potent as a 
chemotherapeutics, and highly effective in treating a range of diseases states involving hyperplastic or dysplastic conditions $(1,2)$. Psoralens are asymmetrical, tricyclic aromatic compounds, containing a pyrone and a furan ring (3-5). Psoralen intercalates into DNA and form monoadducts and interstrand DNA crosslinks upon absorption of one or two photons of UVA light, respectively (5).

The mechanism of how cells repair DNA interstrand crosslinks has remained a challenging problem. It is widely accepted that repair involves proteins associated with the nucleotide excision repair pathway, since NER mutants in both bacteria and mammalian systems are hypersensitive to crosslinking agents (6-10) . Further, cellular studies, suggest that in the absence of these gene products, DNA interstrand crosslinks are not incised and persist in the DNA $(6,7)$. However, nucleotide excision repair alone, as it is currently understood, is unable to account for the repair of these complex lesions. The linkage of both DNA strands to the lesion implies that the normal NER process of displacing the damaged region and resynthesis of cannot occur, since no template strand is available for synthesis. To accommodate this repair, two primary models for interstrand crosslink repair have been proposed $(7,11,12)$. Both propose that the nucleotide excision repair initiates the process, but then speculate that other repair pathways, such as recombination or translesion synthesis are coupled to excision repair to complete repair of the second strand through a multistep, multipathway process $(7,8,11$, 12).

The first model for ICL repair couples the NER pathway to recombination and is based primarily on early in vitro characterizations (13-17). In this model, the UvrABC 
enzyme makes the initial $3^{\prime}$ and $5^{\prime}$ incisions on the furan side of interstrand crosslink. Then, the $3^{\prime} \rightarrow 5^{\prime}$ exonuclease activity of DNA polymerase I forms a gap creating a single strand region in which RecA, the central enzyme involved in homologous recombination, binds and promotes strand exchange with a homologous daughter chromosome $(18,19)$. The strand exchange enables UvrABC to make a second incision on the other strand (pyrone side of the interstrand crosslink) (13-16). In theory, after this occurs, the crosslink could then be removed and the gap re-synthesized using the sister chromosome as a template. RecA-mediated homologous recombination is classically defined as initiating through one of two pathways in Escherichia coli, the RecFOR and RecBCD pathway (19-23) . In order for RecA protein to initiate strand exchange reaction, RecFOR or RecBCD proteins are thought to be necessary to assist RecA to bind substrates containing single strand regions or DNA ends, respectively $(18,24)$. Although it is well established that RecA plays a role in surviving psoralen-induced damage, the comparative contributions of the RecFOR and RecBCD pathways is not known. However, an understanding of which pathway is involved would be useful and could suggest intermediates that arise in the repair process.

In the absence of a daughter chromosome, homologous recombination cannot occur. To account for this, an alternative model proposes that translesion systhesis may be coupled to NER. In this model, after the UvrA-B-C complex makes the initial incisions, the gap opposite to the lesion is resynthesized by translesion polymerases (11, $25,26)$. In principle, once this is accomplished, the UvrA-B-C complex could initiate a second round of incisions on the opposite strand and the damaged region could then be 
removed and the gap resynthesized.

Escherichia coli contain three damage-inducible polymerases that participate in translesion synthesis. In vitro, polymerase II (Pol II) (polB), Pol IV (dinB), and Pol V $(u m u D C)$ are able to incorporate bases opposite to specific lesions in template DNA with higher efficiency than the replicative polymerase (27-34). Pol III and mutants lacking these genes have higher mutation rates in response to different forms of damage, suggesting that they operate similarly in vivo (27-34). Supporting the translesion synthesis-dependent model of crosslink repair, the survival of plasmids containing interstrand crosslinks suggested that repair could occur independently from recombination and replication (26) .There are also conflicting reports about the hypersensitivity of some translesion polymerase mutants to crosslinking agents. One group has reported multiple phenotypes for polymerase II (PolB), including hypersensitivity to nitrogen mustard, an agent that induces interstrand crosslinks among other lesions $(25,33,34)$. However, subsequent studies have failed to confirm these PolB phenotypes $(28,35)$. Furthermore, a subsequent study reported that Pol IV, but not PolB, was able to synthesize past an oligo containing an acrolein interstrand crosslink in vitro (36). However, the role of the translesion polymerases has not been examined for psoralen-induced damage and no systematic study has examined all three polymerases for their contributions to survival in the presence of DNA interstrand crosslinks.

In the second chapter, we reported the relative sensitivities of the NER pathway mutants to psoralen-induced damage and found that Cho contributes to the repair process with UvrC. Here, we characterize and compare the relative contributions of the 
recombination and translesion synthesis pathways in the survival of psoralen-induced damage to better understand the mechanism involved in the repair of these lesions.

\section{MATERIALS AND METHODS}

\section{$\underline{\text { Bacterial Strains }}$}

The parental strain used in this study was SR108, a thyA36 deoC2 derivative of W3110(37). Mutant strains HL952 lacking (SR108 uvrA::Tn10)(38), polB CL636 (del(polB)::omega spc) (35), umuDC CL632 (UmuDC CL632) (35) ,dinB CL634 (del(dinB)::Kan) (35).CL646 (SR108 polB:: $\Omega$ Sm-Sp dinB::Kanr umuDC595::cat) (35), CL681 (SR108 polB:: $\Omega$ Sm-Sp dinB::Kanr umuDC595::cat uvrA::Tn10)(35), recA HL921 (recA::tetR) (38), recBC HL922 (tetR( recBC)) (38), and recF CL579 (SR108 recF6206::Tetr) (38) have been previously reported.

\section{Psoralen UV-A Survival Assay}

Overnight cultures were grown in Davis medium supplemented with $0.4 \%$ glucose, $0.2 \%$ Casamino Acids, and $10 \mu \mathrm{g} / \mathrm{ml}$ thymine (DGCthy). Subcultures were diluted 1:100 and grown at $37^{\circ} \mathrm{C}$ shaker in to an optical density at $600 \mathrm{~nm}$ (OD600) of 0.3. At this time, $10 \mu \mathrm{g} / \mathrm{mL}$ of psoralen was added to the cultures and incubation continued for five more minutes before irradiation with UV-A light. Cells were irradiated using two 32 watt UVA bulbs (Sylvanyia) with a peak emittance of $(320 \mathrm{~nm}$ ) at an incident dose of $6.9 \mathrm{~J} / \mathrm{m} 2 / \mathrm{s}$. After irradiation, cells were serially diluted and $10 \mu \mathrm{l}$ spots of each dilution were plated in triplicate onto LB thy agar plates. Plates were incubated at $37^{\circ} \mathrm{C}$ and colonies were counted the next day to determine the surviving fraction. 


\section{RESULTS}

To examine how the two primary recombination pathways affect survival in the presence of psoralen-induced damage, we compared the survival of mutants defective in each pathway to the wild type strain and a $\operatorname{rec} A$ strain, which is defective in all homologous recombination. To this end, $10 \mu \mathrm{g} / \mathrm{ml} 8$-methoxypsoralen was added to growing cultures of the parental and mutant strains before they were exposed to $6.9 / \mathrm{J} / \mathrm{m} 2 / \mathrm{s}$ UVA irradiation for increasing time periods. The fraction of cells surviving to form colonies at each dose was then determined. Under these conditions, greater than $37 \%$ of wild type cells survive UV-A doses up to $\sim 3 \mathrm{~kJ} / \mathrm{m} 2$, which in the presence of $10 \mu \mathrm{g} / \mathrm{ml}$ 8-methoxypsoralen produces about 45-50 DNA crosslinks per genome (see $\mathrm{Ch}$ 2, Figure 2-4). Although the level of monoadducts could not be determined from this data, these adducts are also likely to contribute to the lethality observed in the population. Consistent with earlier studies, $r e c A$ mutants were highly sensitivity to psoralen-induced DNA damage, and survival was reduced to $37 \%$ with at dose $\sim 0.5 \mathrm{~kJ} / \mathrm{m} 2$, which was similar to that of the nucleotide excision repair defective $u v r A$ strain (Figure 3-1) under our conditions. This dose would correspond to approximately 7 crosslinks per genome, which is also similar to the lethal dose observed in previous studies (7) .We next examined the sensitivity of $r e c F$ and $r e c B C$ mutants. Both $r e c B C$ and $r e c F$ mutants were hypersensitive to psoralen-induced damage, relative to wild type cultures. However, the hypersensitivity of each mutant was more modest than that observed in recA cultures. At higher doses of UV-A light, recF cultures demonstrated slightly more sensitivity to psoralen-induced damage than $\operatorname{rec} B C$ cultures. These results suggest that the repair of 
psoralen-induced damage involves intermediates, or produces substrates that are processed by both the RecFOR and RecBCD pathways.

To examine the role of translesion synthesis in the repair of psoralen-induced DNA damage, we compared the survival of mutants that lack Pol II, Pol IV, Pol V, or all three of the damage inducible DNA polymerases in E. coli following treatment with psoralen plus UVA irradiation as before. Relative to wild type cultures, mutants lacking any single translesion polymerase were generally as resistant as wild type cultures at doses of irradiation below $\sim 1 \mathrm{~kJ} / \mathrm{m} 2$, but exhibited a modest hypersensitivity at higher doses (Figure 3-2). umuDC mutants, lacking Pol V, were significantly more sensitive than either polB (Pol II) or $\operatorname{din} B$ (Pol IV) mutants.. The sensitivity of the triple polymerase mutant lacking all three damage-inducible DNA polymerases was similar to that of the umuDC (Pol V) single mutant, suggesting that Pol V is the predominant polymerase that contributes to survival at psoralen-induced DNA damage. 


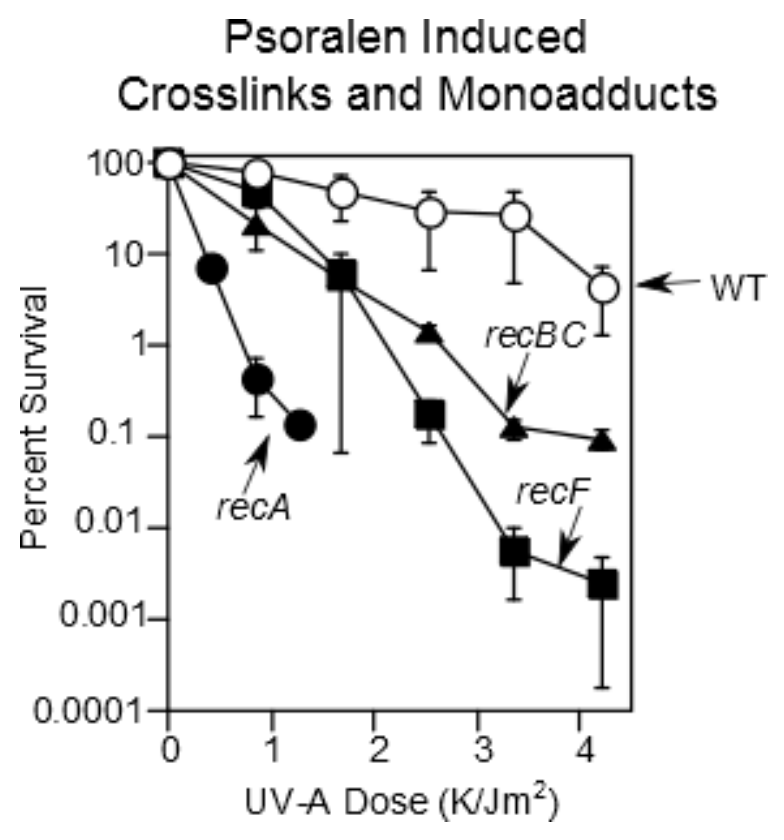

Figure 3-1. Both RecFOR and RecBCD pathways contribute to the survival of psoralen-induced DNA damage. The survival of cells following UV-A (340nm) irradiation in the presence of $10 \mu \mathrm{g} / \mathrm{ml} 8$-methoxy-psoralen is plotted. WT (open circles), recA (closed circles), recF (closed squares), recBC (closed triangles) Graphs represent the average of three or more independent experiments. Error bars represent one standard deviation. 


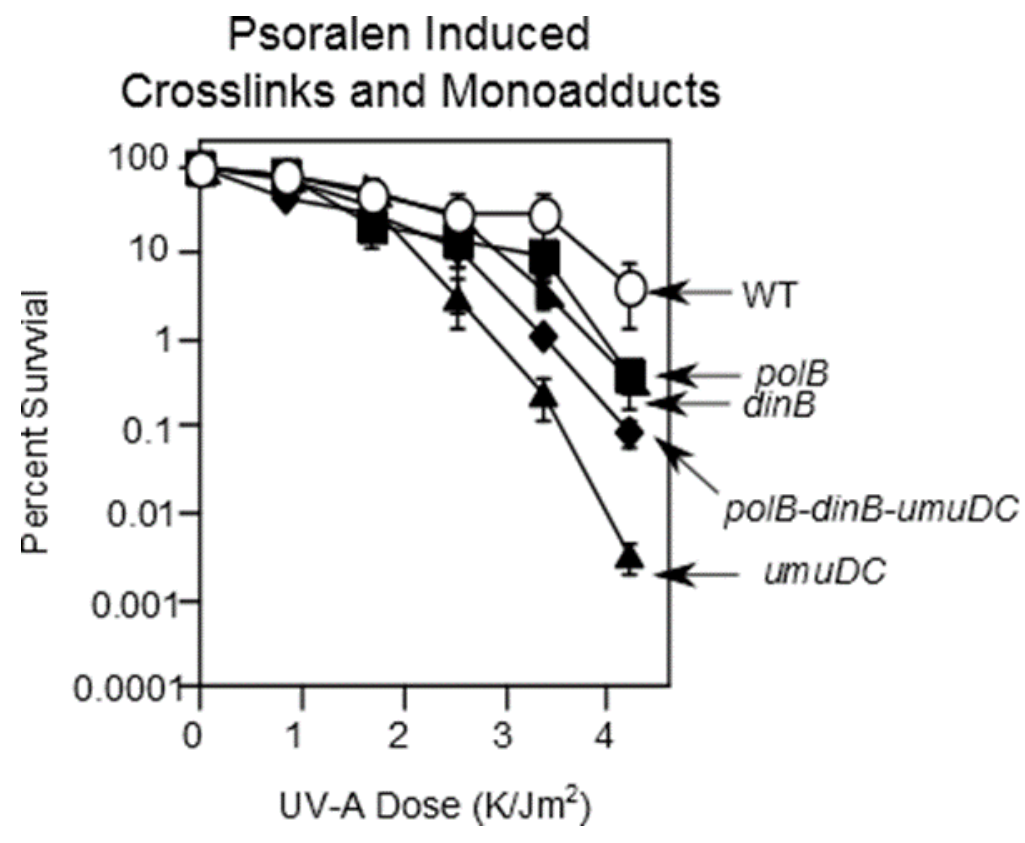

Figure 3-2: Tranlesion Polymerase V, encoded by $u m u D C$ contributes to survival of psoralen-induced damage. The survival of cells following UV-A $(340 \mathrm{~nm})$ irradiation in the presence of $10 \mu \mathrm{g} / \mathrm{ml} 8$-methoxy-psoralen is plotted. WT (open circles), uтиDC (closed isosceles), polB-dinB-umuDC triple mutant (closed diamonds), $\operatorname{din} B$ (closed squares) and polB (closed right triangle). Graphs represent the average of three or more independent experiments. Error bars represent one standard deviation. 


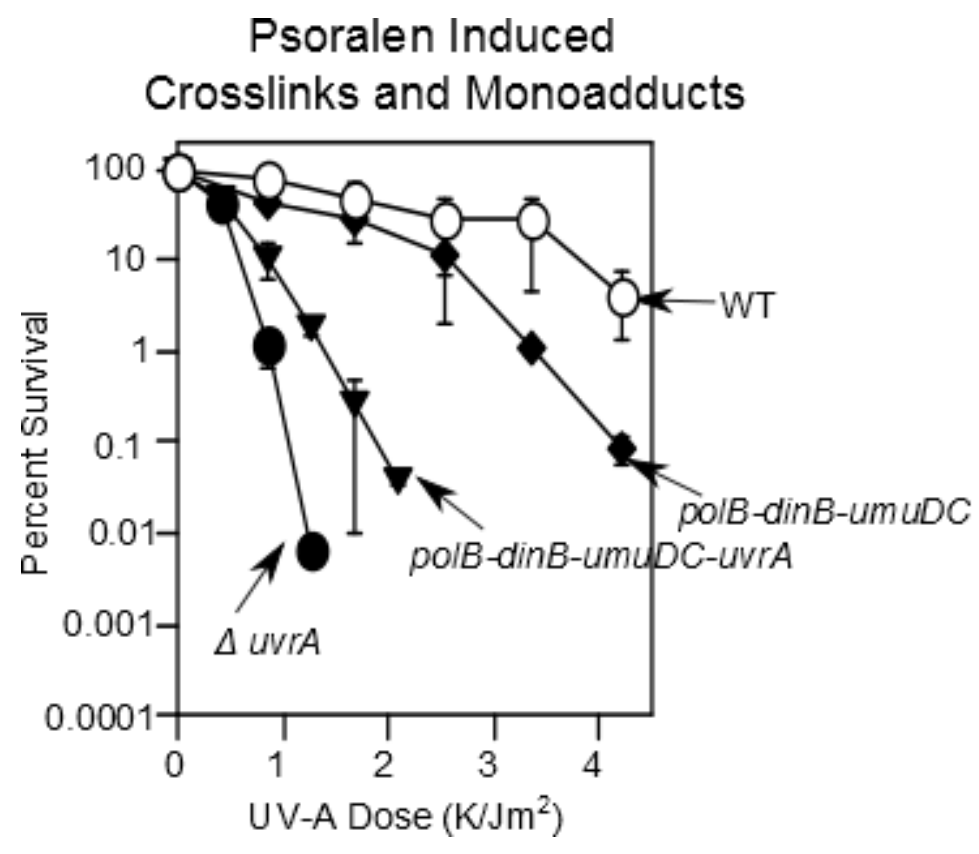

Figure 3-3: UvrA coupled with translesion polymerases increases the sensitivity for the psoralen induced lesions. The survival of cells following UV-A (340nm) irradiation in the presence of $10 \mu \mathrm{g} / \mathrm{ml} 8$-methoxy-psoralen is plotted. WT (open circles), polB-dinBumuDC triple mutants (closed diamonds), polB-dinB-umuDC-uvrA quadraple mutant (closed isosceles), and $u v r A$ (closed circles).Graphs represent the average of three or more independent experiments. Error bars represent one standard deviation. 
I also compared the relative survival of the triple translesion polymerase mutants to that of the nucleotide excision repair, uvrA mutant. The hypersensitivity of the polymerase mutants was distinct from that of $u v r A$ in that the polymerase mutants were not hypersensitive to low doses, and far less hypersensitive overall. This could be interpreted to suggest that that primary contribution of translesion synthesis occurs when the level of DNA damage in the cell exceeds the capacity of the other repair pathways to deal with the lesions. Curiously, the absence of the translesion polymerases modestly increased the resistance of the $u v r A$ mutant, although this mutant remained highly sensitive to psoralen-induced damage (Figure 3-3). This result could indicate that the absence of incisions that initiate repair benefits survival of cells in cases where the polymerases are not present.

\section{DISCUSSION}

Current models of DNA interstrand crosslinks propose that coupling of multiple repair pathways are responsible for the repair of DNA interstrand crosslinks (Reviewed in (12)). One model suggested in the presence of replication, interstrand crosslinks are repaired by collaboration between NER and recombination proteins $(7,8,39)$. We demonstrated in our studies that both the RecF and RecBC recombination pathways are required for full resistance to psoralen-induced lesions. Although both pathways exhibited hypersensitivity, the higher sensitivity of the RecFOR pathway may suggest a role for this replication-associated recombination during the repair process. A significant limitation of this study is that 8-methoxy psoralen induces both DNA interstrand crosslinks and monoadducts. Both the recFOR and $\operatorname{rec} B C D$ pathways are known to by 
hypersensitive to a variety of agents that produce monoadducts, thus, although we can conclude that these pathways contribute to the repair of psoralen-induced damage, we cannot say whether they contribute to DNA interstrand crosslinks.

A second model of crosslink repair suggests that the repair process couples NER with translesion synthesis pathways. According to the model, translesion polymerases assist in bypassing the displaced lesion-containing oligo that remains after the NER proteins make the first incision $(11,12,25)$. A prediction of this model is that the translesion polymerases should be required for the survival of cells containing DNA interstrand crosslinks similar to that of the nucleotide excision repair mutants. However, while we observed that translesion polymerases contributed to cell survival of UVA irradiated cultures treated with psoralen treated, particularly with respect to Pol V $(u m u D C)$, the survival curve was distinct from that the excision repair mutants in several ways. In contrast to $u v r A$, the absence of the polymerases did not affect survival at lower levels of psoralen-induced damage, and the overall hypersensitivity of the polymerase mutants was much less than that of the $u v r A$ mutants. These results would suggest that the polymerase mutants are not acting in the same pathway as nucleotide excision repair in removing these lesions as proposed. Although as noted above, we cannot distinguish between the contributions of the polymerases have in tolerating monoadducts from that of interstrand crosslinks, the differences between the $u v r A$ and polymerase mutant survivals allow us to infer that they are not acting in a single linear repair pathway.

In future work, it may prove informative to compare the survival curves of these strains using both 8-methoxypsoralen and angelicin, similar to the approach used for the 
Cho mutant. This may allow us to differentiate which of these pathways and genes contribute to the repair of monoadducts and DNA interstrand crosslinks. 


\section{REFERENCES}

1. Parrish JA, Fitzpatrick TB, Tanenbaum L, Pathak MA. 1974. Photochemotherapy of Psoriasis with Oral Methoxsalen and Longwave Ultraviolet Light. New England Journal of Medicine 291:1207-1211.

2. Parrish JA, Stern RS, Pathak MA, Fitzpatrick TB. 1982. Photochemotherapy of Skin Diseases, p. 595-623. In Regan J, Parrish J (ed.), The Science of Photomedicine. Springer US.

3. Hearst JE. 1989. Photochemistry of the psoralens. Chemical Research in Toxicology 2:69-75.

4. Hearst JE, Isaacs ST, Kanne D, Rapoport H, Straub K. 1984. The reaction of the psoralens with deoxyribonucleic acid. Quarterly Reviews of Biophysics 17:144.

5. Kitamura N, Kohtani S, Nakagaki R. 2005. Molecular aspects of furocoumarin reactions: Photophysics, photochemistry, photobiology, and structural analysis. Journal of Photochemistry and Photobiology C: Photochemistry Reviews 6:168185.

6. Cole RS. 1973. Repair of DNA Containing Interstrand Crosslinks in Escherichia coli: Sequential Excision and Recombination. Proceedings of the National Academy of Sciences 70:1064-1068.

7. Cole RS, Levitan D, Sinden RR. 1976. Removal of psoralen interstrand crosslinks from DNA of Escherichia coli: Mechanism and genetic control. Journal of Molecular Biology 103:39-59.

8. Bridges BA, Stannard M. 1982. A new pathway for repair of cross-linkable 8methoxypsoralen mono-adducts in Uvr- strains of Escherichia coli. Mutation Research/Fundamental and Molecular Mechanisms of Mutagenesis 92:9-14.

9. Cupido M, Bridges BA. 1985. Uvr-independent repair of 8-methoxypsoralen crosslinks in Escherichia coli: Evidence for a recombinational process. Mutation Research/DNA Repair Reports 146:135-141.

10. Sarkar S, Davies AA, Ulrich HD, McHugh PJ. 2006. DNA interstrand crosslink repair during G1 involves nucleotide excision repair and DNA polymerase $\zeta$. The EMBO Journal 25:1285-1294.

11. Berardini M, Mackay W, Loechler EL. 1997. Evidence for a RecombinationIndependent Pathway for the Repair of DNA Interstrand Cross-Links Based on a Site-Specific Study with Nitrogen Mustard $\dagger$. Biochemistry 36:3506-3513.

12. Dronkert MLG, Kanaar R. 2001. Repair of DNA interstrand cross-links. Mutation Research/DNA Repair 486:217-247.

13. Van Houten B, Gamper H, Hearst JE, Sancar A. 1986. Construction of DNA substrates modified with psoralen at a unique site and study of the action mechanism of $\mathrm{ABC}$ excinuclease on these uniformly modified substrates. Journal of Biological Chemistry 261:14135-14141.

14. Van Houten B, Gamper H, Hearst JE, Sancar A. 1988. Analysis of sequential steps of nucleotide excision repair in Escherichia coli using synthetic substrates containing single psoralen adducts. Journal of Biological Chemistry 263:16553- 
16560.

15. Van Houten B, Gamper H, Holbrook SR, Hearst JE, Sancar A. 1986. Action mechanism of ABC excision nuclease on a DNA substrate containing a psoralen crosslink at a defined position. Proceedings of the National Academy of Sciences 83:8077-8081.

16. Sladek FM, Melian A, Howard-Flanders P. 1989. Incision by UvrABC excinuclease is a step in the path to mutagenesis by psoralen crosslinks in Escherichia coli. Proc Natl Acad Sci U S A 86:3982-3986.

17. Sladek FM, Munn MM, Rupp WD, Howard-Flanders P. 1989. In vitro repair of psoralen-DNA cross-links by RecA, UvrABC, and the 5'-exonuclease of DNA polymerase I. Journal of Biological Chemistry 264:6755-6765.

18. Bichara M, Pinet I, Lambert IB, Fuchs RP. 2007. RecA-mediated excision repair: a novel mechanism for repairing DNA lesions at sites of arrested DNA synthesis. Mol Microbiol 65:218-229.

19. Courcelle J, Carswell-Crumpton C, Hanawalt PC. 1997. recF and recR are required for the resumption of replication at DNA replication forks in Escherichia coli. Proceedings of the National Academy of Sciences 94:37143719.

20. Churchill JJ, Anderson DG, Kowalczykowski SC. 1999. The RecBC enzyme loads RecA protein onto ssDNA asymmetrically and independently of $\chi$, resulting in constitutive recombination activation. Genes \& Development 13:901-911.

21. Morimatsu K, Kowalczykowski SC. 2003. RecFOR Proteins Load RecA Protein onto Gapped DNA to Accelerate DNA Strand Exchange: A Universal Step of Recombinational Repair. Molecular Cell 11:1337-1347.

22. Ayora S, Alonso JC. 1997. Purification and characterization of the RecF protein from Bacillus subtilis 168. Nucleic Acids Research 25:2766-2772.

23. Bork JM, Cox MM, Inman RB. 2001. The RecOR proteins modulate RecA protein function at 5' ends of single-stranded DNA, vol. 20.

24. Kuzminov A. 1999. Recombinational Repair of DNA Damage inEscherichia coli and Bacteriophage $\lambda$. Microbiology and Molecular Biology Reviews 63:751-813.

25. Berardini M, Foster PL, Loechler EL. 1999. DNA Polymerase II (polB) Is Involved in a New DNA Repair Pathway for DNA Interstrand Cross-Links inEscherichia coli. Journal of Bacteriology 181:2878-2882.

26. Wang X, Peterson CA, Zheng H, Nairn RS, Legerski RJ, Li L. 2001. Involvement of Nucleotide Excision Repair in a Recombination-Independent and Error-Prone Pathway of DNA Interstrand Cross-Link Repair. Molecular and Cellular Biology 21:713-720.

27. Napolitano R, Janel-Bintz R, Wagner J, Fuchs RPP. 2000. All three SOSinducible DNA polymerases (Pol II, Pol IV and Pol V) are involved in induced mutagenesis. The EMBO Journal 19:6259-6265.

28. Sutton MD, Farrow MF, Burton BM, Walker GC. 2001. Genetic interactions between the Escherichia coli umuDC gene products and the beta processivity clamp of the replicative DNA polymerase. J Bacteriol 183:2897-2909.

29. Reuven NB, Arad G, Maor-Shoshani A, Livneh Z. 1999. The Mutagenesis 
Protein UmuC Is a DNA Polymerase Activated by UmuD', RecA, and SSB and Is Specialized for Translesion Replication. Journal of Biological Chemistry 274:31763-31766.

30. Woodgate R, Rajagopalan M, Lu C, Echols H. 1989. UmuC mutagenesis protein of Escherichia coli: purification and interaction with UmuD and UmuD'. Proceedings of the National Academy of Sciences 86:7301-7305.

31. Tang M, Shen X, Frank EG, O'Donnell M, Woodgate R, Goodman MF. 1999. UmuD'2C is an error-prone DNA polymerase, Escherichia coli pol V. Proceedings of the National Academy of Sciences 96:8919-8924.

32. Wagner J, Gruz P, Kim S-R, Yamada M, Matsui K, Fuchs RPP, Nohmi T. 1999. The dinB Gene Encodes a Novel E. coli DNA Polymerase, DNA Pol IV, Involved in Mutagenesis. Molecular Cell 4:281-286.

33. Escarceller M, Hicks J, Gudmundsson G, Trump G, Touati D, Lovett S, Foster PL, McEntee K, Goodman MF. 1994. Involvement of Escherichia coli DNA polymerase II in response to oxidative damage and adaptive mutation. Journal of Bacteriology 176:6221-6228.

34. Rangarajan S, Woodgate R, Goodman MF. 1999. A phenotype for enigmatic DNA polymerase II: A pivotal role for pol II in replication restart in UVirradiated Escherichia coli. Proceedings of the National Academy of Sciences 96:9224-9229.

35. Courcelle CT, Belle JJ, Courcelle J. 2005. Nucleotide Excision Repair or Polymerase V-Mediated Lesion Bypass Can Act To Restore UV-Arrested Replication Forks in Escherichia coli. Journal of Bacteriology 187:6953-6961.

36. Kumari A, Minko IG, Harbut MB, Finkel SE, Goodman MF, Lloyd RS. 2008. Replication Bypass of Interstrand Cross-link Intermediates by Escherichia coli DNA Polymerase IV. Journal of Biological Chemistry 283:27433-27437.

37. Mellon I, Hanawalt PC. 1989. Induction of the Escherichia coli lactose operon selectively increases repair of its transcribed DNA strand. Nature 342:95-98.

38. Courcelle J, Crowley DJ, Hanawalt PC. 1999. Recovery of DNA replication in UV-irradiated Escherichia coli requires both excision repair and recF protein function. J Bacteriol 181:916-922.

39. Bridges BA. 1984. Further characterization of repair of 8-methoxypsoralen crosslinks in UV-excision-defective Escherichia coli. Mutation Research/DNA Repair Reports 132:153-160. 


\section{TERMINAL REFERENCES}

1. Pathak MA, Fitzpatrick TB. 1992. The evolution of photochemotherapy with psoralens and UVA (PUVA): 2000 BC to 1992 AD. Journal of Photochemistry and Photobiology B: Biology 14:3-22.

2. Bourgaud F, Hehn A, Larbat R, Doerper S, Gontier E, Kellner S, Matern U. 2006. Biosynthesis of coumarins in plants: a major pathway still to be unravelled for cytochrome P450 enzymes. Phytochem Rev 5:293-308.

3. Pathak MA, Fitzpatrick TB. 1959. Relationship of molecular configuration to the activity of furocoumarins which increase the cutaneous responses following long wave ultraviolet radiation. J Invest Dermatol 32:255-262.

4. Parrish JA, Stern RS, Pathak MA, Fitzpatrick TB. 1982. Photochemotherapy of Skin Diseases, p. 595-623. In Regan J, Parrish J (ed.), The Science of Photomedicine. Springer US.

5. Parrish JA, Fitzpatrick TB, Tanenbaum L, Pathak MA. 1974. Photochemotherapy of Psoriasis with Oral Methoxsalen and Longwave Ultraviolet Light. New England Journal of Medicine 291:1207-1211.

6. Gupta AK, Anderson TF. 1987. Psoralen photochemotherapy. Journal of the American Academy of Dermatology 17:703-734.

7. Querfeld C RSTKTM, et al. 2005. LOng-term follow-up of patients with earlystage cutaneous t-cell lymphoma who achieved complete remission with psoralen plus uv-a monotherapy. Archives of Dermatology 141:305-311.

8. Anderson TF, Voorhees JJ. 1980. Psoralen photochemotherapy of cutaneous disorders. Annual review of pharmacology and toxicology 20:235-257.

9. Baron ED, Stevens SR. 2003. Phototherapy for cutaneous T-cell lymphoma. Dermatologic Therapy 16:303-310.

10. March KL, Patton BL, Wilensky RL, Hathaway DR. 1993.8 Methoxypsoralen and longwave ultraviolet irradiation are a novel antiproliferative combination for vascular smooth muscle. Circulation 87:184-191.

11. Kitamura N, Kohtani S, Nakagaki R. 2005. Molecular aspects of furocoumarin reactions: Photophysics, photochemistry, photobiology, and structural analysis. Journal of Photochemistry and Photobiology C: Photochemistry Reviews 6:168185.

12. Hearst JE. 1989. Photochemistry of the psoralens. Chemical Research in Toxicology 2:69-75.

13. Hearst JE, Isaacs ST, Kanne D, Rapoport H, Straub K. 1984. The reaction of the psoralens with deoxyribonucleic acid. Quarterly Reviews of Biophysics 17:144.

14. Tessman JW, Isaacs ST, Hearst JE. 1985. Photochemistry of the furan-side 8methoxypsoralen-thymidine monoadduct inside the DNA helix. Conversion to diadduct and to pyrone-side monoadduct. Biochemistry 24:1669-1676.

15. Ashwood-Smith MJ, Grant E. 1977. Conversion of psoralen DNA monoadducts in E. coli to interstrand DNA cross links by near UV light (320-360 nm): Inability 
of angelicin to form cross links, in vivo. Experientia 33:384-386.

16. Bordin F, Carlassare F, Baccichetti F, Anselmo L. 1976. DNA repair and recovery in Escherichia coli after psoralen and angelicin photosensitization. Biochimica et Biophysica Acta (BBA) - Nucleic Acids and Protein Synthesis 447:249-259.

17. Dronkert MLG, Kanaar R. 2001. Repair of DNA interstrand cross-links. Mutation Research/DNA Repair 486:217-247.

18. Berardini M, Foster PL, Loechler EL. 1999. DNA Polymerase II (polB) Is Involved in a New DNA Repair Pathway for DNA Interstrand Cross-Links inEscherichia coli. Journal of Bacteriology 181:2878-2882.

19. Berardini M, Mackay W, Loechler EL. 1997. Evidence for a RecombinationIndependent Pathway for the Repair of DNA Interstrand Cross-Links Based on a Site-Specific Study with Nitrogen Mustard $\dagger$. Biochemistry 36:3506-3513.

20. Cole RS. 1973. Repair of DNA Containing Interstrand Crosslinks in Escherichia coli: Sequential Excision and Recombination. Proceedings of the National Academy of Sciences 70:1064-1068.

21. Cole RS, Levitan D, Sinden RR. 1976. Removal of psoralen interstrand crosslinks from DNA of Escherichia coli: Mechanism and genetic control. Journal of Molecular Biology 103:39-59.

22. Sladek FM, Munn MM, Rupp WD, Howard-Flanders P. 1989. In vitro repair of psoralen-DNA cross-links by RecA, UvrABC, and the 5'-exonuclease of DNA polymerase I. Journal of Biological Chemistry 264:6755-6765.

23. Setlow RB, Carrier WL. 1964. THE DISAPPEARANCE OF THYMINE DIMERS FROM DNA: AN ERROR-CORRECTING MECHANISM. Proceedings of the National Academy of Sciences of the United States of America 51:226-231.

24. Sancar A, Franklin KA, Sancar GB. 1984. Escherichia coli DNA photolyase stimulates uvrABC excision nuclease in vitro. Proceedings of the National Academy of Sciences 81:7397-7401.

25. Truglio JJ, Croteau DL, Van Houten B, Kisker C. 2006. Prokaryotic nucleotide excision repair: the UvrABC system. Chem Rev 106:233-252.

26. Pettijohn D, Hanawalt P. 1964. Evidence for repair-replication of ultraviolet damaged DNA in bacteria. Journal of Molecular Biology 9:395-410.

27. Sancar A. 1996. DNA excision repair. Annu Rev Biochem 65:43-81.

28. Van Houten B. 1990. Nucleotide excision repair in Escherichia coli. Microbiol Rev 54:18-51.

29. Snowden A, Kow YW, Van Houten B. 1990. Damage repertoire of the Escherichia coli UvrABC nuclease complex includes abasic sites, base-, damage analogues, and lesions containing adjacent 5' or 3' nicks. Biochemistry 29:72517259.

30. Seeberg E, Steinum AL. 1982. Purification and properties of the uvrA protein from Escherichia coli. Proc Natl Acad Sci U S A 79:988-992.

31. Verhoeven EEA, Wyman C, Moolenaar GF, Goosen N. 2002. The presence of two UvrB subunits in the UvrAB complex ensures damage detection in both DNA strands. The EMBO Journal 21:4196-4205. 
32. Sancar A, Reardon JT. 2004. Nucleotide Excision Repair in E. Coli and Man, p. 43-71. In Wei Y (ed.), Advances in Protein Chemistry, vol. Volume 69. Academic Press.

33. Verhoeven EEA, Wyman C, Moolenaar GF, Hoeijmakers JHJ, Goosen N. 2001. Architecture of nucleotide excision repair complexes: DNA is wrapped by UvrB before and after damage recognition. The EMBO Journal 20:601-611.

34. Verhoeven EEA, van Kesteren M, Moolenaar GF, Visse R, Goosen N. 2000. Catalytic Sites for 3' and 5' Incision of Escherichia coli Nucleotide Excision Repair Are Both Located in UvrC. Journal of Biological Chemistry 275:51205123.

35. Sancar A, Rupp WD. 1983. A novel repair enzyme: UVRABC excision nuclease of Escherichia coli cuts a DNA strand on both sides of the damaged region. Cell 33:249-260.

36. Yeung AT, Mattes WB, Oh EY, Grossman L. 1983. Enzymatic properties of purified Escherichia coli uvrABC proteins. Proceedings of the National Academy of Sciences 80:6157-6161.

37. Moolenaar GF, Franken KLMC, Dijkstra DM, Thomas-Oates JE, Visse R, van de Putte P, Goosen N. 1995. The C-terminal Region of the UvrB Protein of Escherichia coli Contains an Important Determinant for UvrC Binding to the Preincision Complex but Not the Catalytic Site for 3'-Incision. Journal of Biological Chemistry 270:30508-30515.

38. Moolenaar GF, Uiterkamp RS, Zwijnenburg DA, Goosen N. 1998. The Cterminal region of the Escherichia coli UvrC protein, which is homologous to the $\mathrm{C}$-terminal region of the human ERCC1 protein, is involved in DNA binding and 5'-incision. Nucleic Acids Res 26:462-468.

39. Singh S, Folkers GE, Bonvin AMJJ, Boelens R, Wechselberger R, Niztayev A, Kaptein R. 2002. Solution structure and DNA-binding properties of the Cterminal domain of UvrC from E.coli. The EMBO Journal 21:6257-6266.

40. Sibghat U, Sancar A, Hearst JE. 1990. The repair patch of E. coli (A)BC excinuclease. Nucleic Acids Res 18:5051-5053.

41. Husain I, Van Houten B, Thomas DC, Abdel-Monem M, Sancar A. 1985. Effect of DNA polymerase I and DNA helicase II on the turnover rate of UvrABC excision nuclease. Proc Natl Acad Sci U S A 82:6774-6778.

42. Moolenaar GF, van Rossum-Fikkert S, van Kesteren M, Goosen N. 2002. Cho, a second endonuclease involved in Escherichia coli nucleotide excision repair. Proceedings of the National Academy of Sciences 99:1467-1472.

43. Van Houten B, Eisen JA, Hanawalt PC. 2002. A cut above: Discovery of an alternative excision repair pathway in bacteria. Proceedings of the National Academy of Sciences 99:2581-2583.

44. Kuzminov A. 1999. Recombinational Repair of DNA Damage inEscherichia coli and Bacteriophage $\lambda$. Microbiology and Molecular Biology Reviews 63:751-813.

45. Michel B, Ehrlich SD, Uzest M. 1997. DNA double-strand breaks caused by replication arrest. The EMBO Journal 16:430-438.

46. Yu-Chin T, Jai-Li H, Wang T-CV. 1994. Involvement of RecF pathway recombination genes in postreplication repair in UV-irradiated Escherichia coli 
cells. Mutation Research/DNA Repair 315:1-9.

47. Kahn R, Cunningham RP, DasGupta C, Radding CM. 1981. Polarity of heteroduplex formation promoted by Escherichia coli recA protein. Proceedings of the National Academy of Sciences 78:4786-4790.

48. Konforti BB, Davis RW. 1987. 3' homologous free ends are required for stable joint molecule formation by the RecA and single-stranded binding proteins of Escherichia coli. Proceedings of the National Academy of Sciences 84:690-694.

49. Cassuto E, West SC, Howard-Flanders P. 1982. Can recA protein promote homologous pairing between duplex regions of DNA? The EMBO Journal 1:821825.

50. Courcelle J, Carswell-Crumpton C, Hanawalt PC. 1997. recF and recR are required for the resumption of replication at DNA replication forks in Escherichia coli. Proceedings of the National Academy of Sciences 94:37143719.

51. Anderson DG, Kowalczykowski SC. 1997. The Translocating RecBCD Enzyme Stimulates Recombination by Directing RecA Protein onto ssDNA in a $\chi$ Regulated Manner. Cell 90:77-86.

52. Churchill JJ, Anderson DG, Kowalczykowski SC. 1999. The RecBC enzyme loads RecA protein onto ssDNA asymmetrically and independently of $\chi$, resulting in constitutive recombination activation. Genes \& Development 13:901-911.

53. Taylor AF, Smith GR. 2003. RecBCD enzyme is a DNA helicase with fast and slow motors of opposite polarity. Nature 423:889-893.

54. Dillingham MS, Spies M, Kowalczykowski SC. 2003. RecBCD enzyme is a bipolar DNA helicase. Nature 423:893-897.

55. Chow K-H, Courcelle J. 2004. RecO Acts with RecF and RecR to Protect and Maintain Replication Forks Blocked by UV-induced DNA Damage in Escherichia coli. Journal of Biological Chemistry 279:3492-3496.

56. Chen Z, Ricigliano JW, Klessig DF. 1993. Purification and characterization of a soluble salicylic acid-binding protein from tobacco. Proceedings of the National Academy of Sciences 90:9533-9537.

57. Courcelle J, Crowley DJ, Hanawalt PC. 1999. Recovery of DNA replication in $\mathrm{UV}$-irradiated Escherichia coli requires both excision repair and recF protein function. J Bacteriol 181:916-922.

58. Ho TV, Schärer OD. 2010. Translesion DNA synthesis polymerases in DNA interstrand crosslink repair. Environmental and Molecular Mutagenesis 51:552566.

59. Kumari A, Minko IG, Harbut MB, Finkel SE, Goodman MF, Lloyd RS. 2008. Replication Bypass of Interstrand Cross-link Intermediates by Escherichia coli DNA Polymerase IV. Journal of Biological Chemistry 283:27433-27437.

60. Courcelle CT, Belle JJ, Courcelle J. 2005. Nucleotide Excision Repair or Polymerase V-Mediated Lesion Bypass Can Act To Restore UV-Arrested Replication Forks in Escherichia coli. Journal of Bacteriology 187:6953-6961.

61. Fijalkowska IJ, Schaaper RM, Jonczyk P. 2012. DNA replication fidelity in Escherichia coli: a multi-DNA polymerase affair, vol. 36.

62. Ho TV, Guainazzi A, Derkunt SB, Enoiu M, Schärer OD. 2011. Structure- 
dependent bypass of DNA interstrand crosslinks by translesion synthesis polymerases. Nucleic Acids Research 39:7455-7464.

63. Bagg A, Kenyon CJ, Walker GC. 1981. Inducibility of a gene product required for UV and chemical mutagenesis in Escherichia coli. Proceedings of the National Academy of Sciences 78:5749-5753.

64. Iwasaki H, Nakata A, Walker GC, Shinagawa H. 1990. The Escherichia coli polB gene, which encodes DNA polymerase II, is regulated by the SOS system. Journal of Bacteriology 172:6268-6273.

65. Reuven NB, Arad G, Maor-Shoshani A, Livneh Z. 1999. The Mutagenesis Protein UmuC Is a DNA Polymerase Activated by UmuD', RecA, and SSB and Is Specialized for Translesion Replication. Journal of Biological Chemistry 274:31763-31766.

66. Bonner CA, Hays S, McEntee K, Goodman MF. 1990. DNA polymerase II is encoded by the DNA damage-inducible dinA gene of Escherichia coli. Proceedings of the National Academy of Sciences 87:7663-7667.

67. Wagner J, Gruz P, Kim S-R, Yamada M, Matsui K, Fuchs RPP, Nohmi T. 1999. The dinB Gene Encodes a Novel E. coli DNA Polymerase, DNA Pol IV, Involved in Mutagenesis. Molecular Cell 4:281-286.

68. Napolitano R, Janel-Bintz R, Wagner J, Fuchs RPP. 2000. All three SOSinducible DNA polymerases (Pol II, Pol IV and Pol V) are involved in induced mutagenesis. The EMBO Journal 19:6259-6265.

69. Lehmann AR, Niimi A, Ogi T, Brown S, Sabbioneda S, Wing JF, Kannouche PL, Green CM. 2007. Translesion synthesis: Y-family polymerases and the polymerase switch. DNA Repair 6:891-899.

70. Sanders LH, Rockel A, Lu H, Wozniak DJ, Sutton MD. 2006. Role of Pseudomonas aeruginosa dinB-Encoded DNA Polymerase IV in Mutagenesis. Journal of Bacteriology 188:8573-8585.

71. Knipscheer P, Raschle M, Smogorzewska A, Enoiu M, Ho TV, Scharer OD, Elledge SJ, Walter JC. 2009. The Fanconi anemia pathway promotes replication-dependent DNA interstrand cross-link repair. Science 326:1698-1701.

72. Williams HL, Gottesman ME, Gautier J. 2012. Replication-independent repair of DNA interstrand crosslinks. Mol Cell 47:140-147.

73. Williams HL, Gottesman ME, Gautier J. 2013. The differences between ICL repair during and outside of S phase. Trends Biochem Sci 38:386-393.

74. Patel KJ, Joenje H. 2007. Fanconi anemia and DNA replication repair. DNA Repair 6:885-890.

75. Castillo Bosch P, Segura-Bayona S, Koole W, van Heteren JT, Dewar JM, Tijsterman M, Knipscheer P. 2014. FANCJ promotes DNA synthesis through G-quadruplex structures. Embo J 5.

76. Huang M, Kim JM, Shiotani B, Yang K, Zou L, D'Andrea AD. 2010. The FANCM/FAAP24 Complex Is Required for the DNA Interstrand CrosslinkInduced Checkpoint Response. Molecular Cell 39:259-268.

77. Klein Douwel D, Boonen Rick ACM, Long David T, Szypowska Anna A, Räschle M, Walter Johannes C, Knipscheer P. 2014. XPF-ERCC1 Acts in Unhooking DNA Interstrand Crosslinks in Cooperation with FANCD2 and 
FANCP/SLX4. Molecular Cell 54:460-471.

78. Clingen PH, De Silva IU, McHugh PJ, Ghadessy FJ, Tilby MJ, Thurston DE, Hartley JA. 2005. The XPF-ERCC1 endonuclease and homologous recombination contribute to the repair of minor groove DNA interstrand crosslinks in mammalian cells produced by the pyrrolo[2,1-c][1,4]benzodiazepine dimer SJG-136. Nucleic Acids Research 33:3283-3291.

79. Park C-H, Bessho T, Matsunaga T, Sancar A. 1995. Purification and Characterization of the XPF-ERCC1 Complex of Human DNA Repair Excision Nuclease. Journal of Biological Chemistry 270:22657-22660.

80. Bhagwat N, Olsen AL, Wang AT, Hanada K, Stuckert P, Kanaar R, D'Andrea A, Niedernhofer LJ, McHugh PJ. 2009. XPF-ERCC1 Participates in the Fanconi Anemia Pathway of Cross-Link Repair. Molecular and Cellular Biology 29:6427-6437.

81. Matsunaga T, Park C-H, Bessho T, Mu D, Sancar A. 1996. Replication Protein A Confers Structure-specific Endonuclease Activities to the XPF-ERCC1 and XPG Subunits of Human DNA Repair Excision Nuclease. Journal of Biological Chemistry 271:11047-11050.

82. Matsunaga T, Mu D, Park C-H, Reardon JT, Sancar A. 1995. Human DNA Repair Excision Nuclease: ANALYSIS OF THE ROLES OF THE SUBUNITS INVOLVED IN DUAL INCISIONS BY USING ANTI-XPG AND ANTIERCC1 ANTIBODIES. Journal of Biological Chemistry 270:20862-20869.

83. Smogorzewska A, Desetty R, Saito TT, Schlabach M, Lach FP, Sowa ME, Clark AB, Kunkel TA, Harper JW, Colaiácovo MP, Elledge SJ. 2010. A Genetic Screen Identifies FAN1, a Fanconi Anemia-Associated Nuclease Necessary for DNA Interstrand Crosslink Repair. Molecular Cell 39:36-47.

84. Kottemann MC, Smogorzewska A. 2013. Fanconi anaemia and the repair of Watson and Crick DNA crosslinks. Nature 493:356-363.

85. Liu T, Ghosal G, Yuan J, Chen J, Huang J. 2010. FAN1 Acts with FANCIFANCD2 to Promote DNA Interstrand Cross-Link Repair. Science 329:693-696.

86. Hanada K, Budzowska M, Modesti M, Maas A, Wyman C, Essers J, Kanaar R. 2006. The structure-specific endonuclease Mus81-Eme1 promotes conversion of interstrand DNA crosslinks into double-strands breaks. The EMBO Journal 25:4921-4932.

87. Van Houten B, Gamper H, Hearst JE, Sancar A. 1986. Construction of DNA substrates modified with psoralen at a unique site and study of the action mechanism of $\mathrm{ABC}$ excinuclease on these uniformly modified substrates. Journal of Biological Chemistry 261:14135-14141.

88. Van Houten B, Gamper H, Hearst JE, Sancar A. 1988. Analysis of sequential steps of nucleotide excision repair in Escherichia coli using synthetic substrates containing single psoralen adducts. Journal of Biological Chemistry 263:1655316560.

89. Van Houten B, Gamper H, Holbrook SR, Hearst JE, Sancar A. 1986. Action mechanism of ABC excision nuclease on a DNA substrate containing a psoralen crosslink at a defined position. Proceedings of the National Academy of Sciences 83:8077-8081. 
90. Sladek FM, Melian A, Howard-Flanders P. 1989. Incision by UvrABC excinuclease is a step in the path to mutagenesis by psoralen crosslinks in Escherichia coli. Proc Natl Acad Sci U S A 86:3982-3986.

91. Wang X, Peterson CA, Zheng H, Nairn RS, Legerski RJ, Li L. 2001. Involvement of Nucleotide Excision Repair in a Recombination-Independent and Error-Prone Pathway of DNA Interstrand Cross-Link Repair. Molecular and Cellular Biology 21:713-720.

92. Kelly Jr EW, Pinkus H. 1955. Local Application of 8-Methoxypsoralen in Vitiligo1. The Journal of Investigative Dermatology 25:453-456.

93. Newburger AE. 1990. Carcinogenesis - a comprehensive study: Skin tumors: experimental and clinical aspects. Archives of Dermatology 126:261-261.

94. Oh EY, Claassen L, Thiagalingam S, Mazur S, Grossman L. 1989. ATPase activity of the UvrA and UvrAB protein complexes of the Escherichia coli UvrABC endonuclease. Nucleic Acids Res 17:4145-4159.

95. Oh EY, Grossman L. 1989. Characterization of the helicase activity of the Escherichia coli UvrAB protein complex. J Biol Chem 264:1336-1343.

96. Verhoeven EE, van Kesteren M, Turner JJ, van der Marel GA, van Boom JH, Moolenaar GF, Goosen N. 2002. The C-terminal region of Escherichia coli UvrC contributes to the flexibility of the UvrABC nucleotide excision repair system. Nucleic Acids Res 30:2492-2500.

97. Bridges BA, Stannard M. 1982. A new pathway for repair of cross-linkable 8methoxypsoralen mono-adducts in Uvr- strains of Escherichia coli. Mutation Research/Fundamental and Molecular Mechanisms of Mutagenesis 92:9-14.

98. Bridges BA. 1984. Further characterization of repair of 8-methoxypsoralen crosslinks in UV-excision-defective Escherichia coli. Mutation Research/DNA Repair Reports 132:153-160.

99. Lage C, Gonçalves SRF, Souza LL, Pádula Md, Leitão AC. 2010. Differential survival of Escherichia coli uvrA, uvrB, and uvrC mutants to psoralen plus UV-A (PUVA): Evidence for uncoupled action of nucleotide excision repair to process DNA adducts. Journal of Photochemistry and Photobiology B: Biology 98:40-47.

100. Boyce R, Howard-Flanders P. 1964. Genetic control of DNA breakdown and repair inE. coli K-12 treated with mitomycin C or ultraviolet light. Zeitschrift für Vererbungslehre 95:345-350.

101. Cupido M, Bridges BA. 1985. Uvr-independent repair of 8-methoxypsoralen crosslinks in Escherichia coli: Evidence for a recombinational process. Mutation Research/DNA Repair Reports 146:135-141.

102. Howard-Flanders P, Boyce RP, Theriot L. 1966. THREE LOCI IN ESCHERICHIA COLI K-12 THAT CONTROL THE EXCISION OF PYRIMIDINE DIMERS AND CERTAIN OTHER MUTAGEN PRODUCTS FROM DNA. Genetics 53:1119-1136.

103. Howard-Flanders P, Theriot L. 1966. Mutants of Escherichia coli K-12 defective in DNA repair and in genetic recombination. Genetics 53:1137-1150.

104. Newton KN, Courcelle CT, Courcelle J. 2012. UvrD Participation in Nucleotide Excision Repair Is Required for the Recovery of DNA Synthesis following UVInduced Damage in Escherichia coli. J Nucleic Acids 271453:27. 
105. Yu D, Ellis HM, Lee EC, Jenkins NA, Copeland NG, Court DL. 2000. An efficient recombination system for chromosome engineering in Escherichia coli. Proc Natl Acad Sci U S A 97:5978-5983.

106. Dewitt SK, Adelberg EA. 1962. The Occurrence of a Genetic Transposition in a Strain of Escherichia Coli. Genetics 47:577-585.

107. Mitchell DL, Nairn RS. 1989. The biology of the (6-4) photoproduct. Photochem Photobiol 49:805-819.

108. Mitchell DL, Haipek CA, Clarkson JM. 1985. (6-4)Photoproducts are removed from the DNA of UV-irradiated mammalian cells more efficiently than cyclobutane pyrimidine dimers. Mutat Res 143:109-112.

109. Sancar A, Tang M-s. 1993. NUCLEOTIDE EXCISION REPAIR. Photochemistry and Photobiology 57:905-921.

110. Munn MM, Rupp WD. 1991. Interaction of the UvrABC endonuclease with DNA containing a psoralen monoadduct or cross-link. Differential effects of superhelical density and comparison of preincision complexes. J Biol Chem 266:24748-24756.

111. Courcelle J, Donaldson J, Chow K, Courcelle C. 2003. DNA damage-induced replication fork regression and processing in Escherichia coli. Science (New York) 299:1064-1067.

112. Ramaswamy M, Yeung AT. 1994. Sequence-specific interactions of UvrABC endonuclease with psoralen interstrand cross-links. Journal of Biological Chemistry 269:485-492.

113. Jones BK, Yeung AT. 1990. DNA base composition determines the specificity of UvrABC endonuclease incision of a psoralen cross-link. J Biol Chem 265:34893496.

114. Courcelle J, Khodursky A, Peter B, Brown PO, Hanawalt PC. 2001. Comparative Gene Expression Profiles Following UV Exposure in Wild-Type and SOS-Deficient Escherichia coli. Genetics 158:41-64.

115. Sarkar S, Davies AA, Ulrich HD, McHugh PJ. 2006. DNA interstrand crosslink repair during G1 involves nucleotide excision repair and DNA polymerase $\zeta$. The EMBO Journal 25:1285-1294.

116. Bichara M, Pinet I, Lambert IB, Fuchs RP. 2007. RecA-mediated excision repair: a novel mechanism for repairing DNA lesions at sites of arrested DNA synthesis. Mol Microbiol 65:218-229.

117. Morimatsu K, Kowalczykowski SC. 2003. RecFOR Proteins Load RecA Protein onto Gapped DNA to Accelerate DNA Strand Exchange: A Universal Step of Recombinational Repair. Molecular Cell 11:1337-1347.

118. Ayora S, Alonso JC. 1997. Purification and characterization of the RecF protein from Bacillus subtilis 168. Nucleic Acids Research 25:2766-2772.

119. Bork JM, Cox MM, Inman RB. 2001. The RecOR proteins modulate RecA protein function at 5' ends of single-stranded DNA, vol. 20.

120. Sutton MD, Farrow MF, Burton BM, Walker GC. 2001. Genetic interactions between the Escherichia coli umuDC gene products and the beta processivity clamp of the replicative DNA polymerase. J Bacteriol 183:2897-2909. 
121. Woodgate R, Rajagopalan M, Lu C, Echols H. 1989. UmuC mutagenesis protein of Escherichia coli: purification and interaction with UmuD and UmuD'. Proceedings of the National Academy of Sciences 86:7301-7305.

122. Tang M, Shen X, Frank EG, O'Donnell M, Woodgate R, Goodman MF. 1999. UmuD'2C is an error-prone DNA polymerase, Escherichia coli pol V. Proceedings of the National Academy of Sciences 96:8919-8924.

123. Escarceller M, Hicks J, Gudmundsson G, Trump G, Touati D, Lovett S, Foster PL, McEntee K, Goodman MF. 1994. Involvement of Escherichia coli DNA polymerase II in response to oxidative damage and adaptive mutation. Journal of Bacteriology 176:6221-6228.

124. Rangarajan S, Woodgate R, Goodman MF. 1999. A phenotype for enigmatic DNA polymerase II: A pivotal role for pol II in replication restart in UVirradiated Escherichia coli. Proceedings of the National Academy of Sciences 96:9224-9229.

125. Mellon I, Hanawalt PC. 1989. Induction of the Escherichia coli lactose operon selectively increases repair of its transcribed DNA strand. Nature 342:95-98.

126. Morliere P, Moysan A, Santus R, Huppe G, Maziere JC, Dubertret L. 1991. UVA-induced lipid peroxidation in cultured human fibroblasts. Biochimica et biophysica acta 1084:261-268.

127. Schalow BJ, Courcelle CT, Courcelle J. 2011. Escherichia coli Fpg glycosylase is nonrendundant and required for the rapid global repair of oxidized purine and pyrimidine damage in vivo. J Mol Biol 410:183-193. 


\section{APPENDIX}

\section{ROLE OF BASE EXCISION REPAIR PATHWAY AND NER ACCESSORY PROTEINS IN SURVIVAL OF DNA INTERSTRAND CROSSLINKS}

UvrD is the helicase associated with nucleotide excision repair. Following dual incisions by UvrABC, UvrD displaces the oligo containing the lesion (1), well as the Nucleotide Excision Repair Complex that is bound to the lesion (2). I compared the survival of $u v r D$ mutants to that of wildtype and other nucleotide excision repair mutants following psoralen- and UV-induced DNA damage.
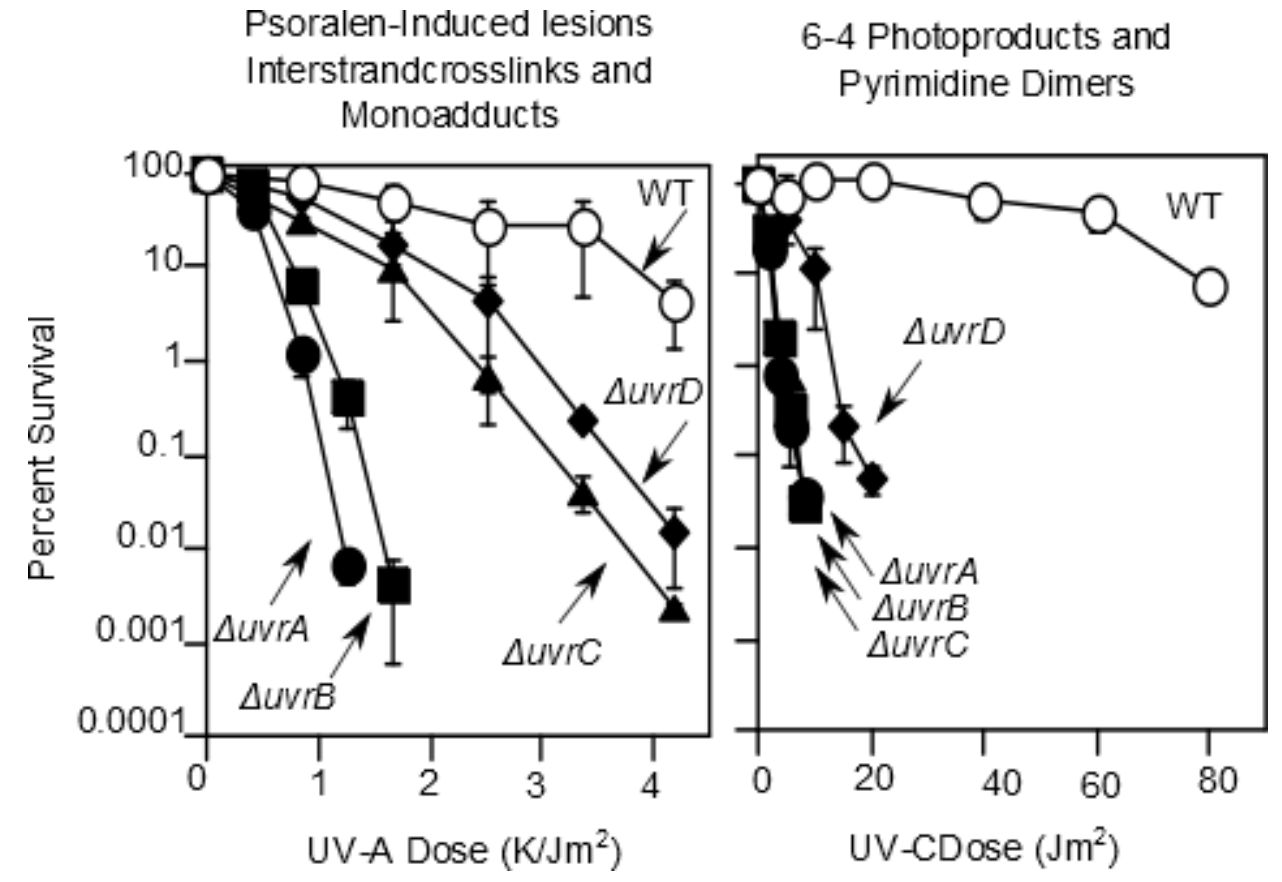

Figure 1: $u v r D$ is less sensitive to psoralen- and UV-induced damage than other components of nucleotide excision repair. The survival of cells following irriadiation with (A) UV-A light $(340 \mathrm{~nm})$ in the presence of $10 \mu \mathrm{g} / \mathrm{ml} 8$-methoxy-psoralen or (B) UVC light $(254 \mathrm{~nm})$ is plotted. WT (open circles), $u v r A$ (closed circles), $u v r B$ (closed square), $u v r C$ (closed triangles) and $u v r D$ (closed diamonds).Graphs represent the average of three independent experiments. Error bars represent one standard deviation. 
Irradiation with UVA by itself is known to generate significant levels of oxygen free radicals that lead to oxidative DNA damage (3) and mutants lacking Exonuclease III (xth) or Endonuclease IV are hypersensitive to oxidative DNA damage (4).To assess whether the level of oxidative DNA damage generated by the irradiation conditions used in this study could be contributing to the lethality observed on our various strains, we compared the survival of $x$ th and nfo mutants to wild type cultures.

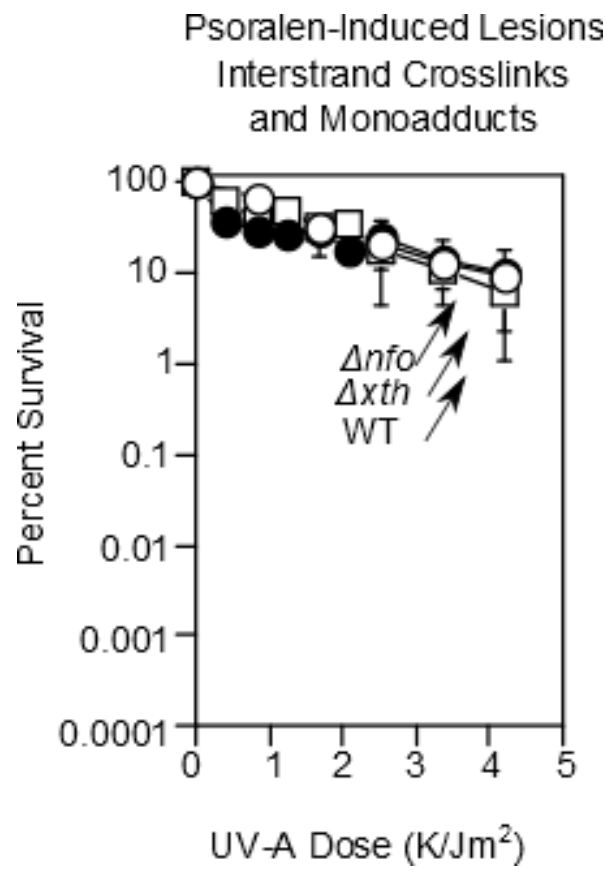

Figure 2: Under the conditions used in this study, nfo and xth mutants are as resistant to psoralen-induced damage as wildtype cultures. The survival of cells following irriadiation with UV-A light $(340 \mathrm{~nm})$ in the presence of $10 \mu \mathrm{g} / \mathrm{ml} 8$-methoxypsoralen is plotted..WT (open circles), nfo (closed circles) and $x t h$ (open square).Graphs represent the average of three independent experiments. Error bars represent one standard deviation. 


\section{REFERENCES}

1. Husain I, Van Houten B, Thomas DC, Abdel-Monem M, Sancar A. 1985. Effect of DNA polymerase I and DNA helicase II on the turnover rate of UvrABC excision nuclease. Proc Natl Acad Sci U S A 82:6774-6778.

2. Sibghat U, Sancar A, Hearst JE. 1990. The repair patch of E. coli (A)BC excinuclease. Nucleic Acids Res 18:5051-5053.

3. Morliere P, Moysan A, Santus R, Huppe G, Maziere JC, Dubertret L. 1991. UVA-induced lipid peroxidation in cultured human fibroblasts. Biochimica et biophysica acta 1084:261-268.

4. Schalow BJ, Courcelle CT, Courcelle J. 2011. Escherichia coli Fpg glycosylase is nonrendundant and required for the rapid global repair of oxidized purine and pyrimidine damage in vivo. J Mol Biol 410:183-193. 